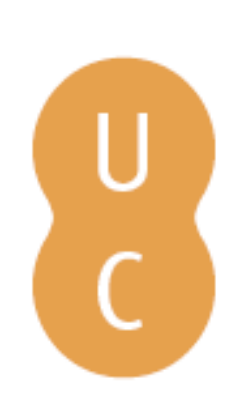

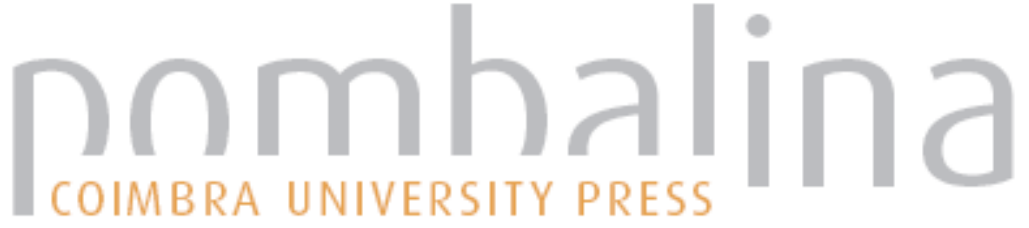

\section{Suporte básico e noções de suporte avançado de vida pediátrico}

\author{
Autor(es): $\quad$ Pinto, Carla \\ Publicado por: Imprensa da Universidade de Coimbra \\ URL \\ persistente: URI:http://hdl.handle.net/10316.2/43109 \\ DOI: $\quad$ DOI:https://doi.org/10.14195/978-989-26-1300-0_8
}

Accessed : $\quad$ 26-Apr-2023 13:17:32

A navegação consulta e descarregamento dos títulos inseridos nas Bibliotecas Digitais UC Digitalis, UC Pombalina e UC Impactum, pressupõem a aceitação plena e sem reservas dos Termos e Condições de Uso destas Bibliotecas Digitais, disponíveis em https://digitalis.uc.pt/pt-pt/termos.

Conforme exposto nos referidos Termos e Condições de Uso, o descarregamento de títulos de acesso restrito requer uma licença válida de autorização devendo o utilizador aceder ao(s) documento(s) a partir de um endereço de IP da instituição detentora da supramencionada licença.

Ao utilizador é apenas permitido o descarregamento para uso pessoal, pelo que o emprego do(s) título(s) descarregado(s) para outro fim, designadamente comercial, carece de autorização do respetivo autor ou editor da obra.

Na medida em que todas as obras da UC Digitalis se encontram protegidas pelo Código do Direito de Autor e Direitos Conexos e demais legislação aplicável, toda a cópia, parcial ou total, deste documento, nos casos em que é legalmente admitida, deverá conter ou fazer-se acompanhar por este aviso.

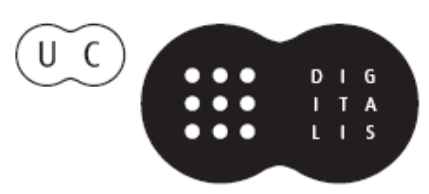


Capítulo 8.

Suporte básico e noções de suporte avançado de vida pediátrico

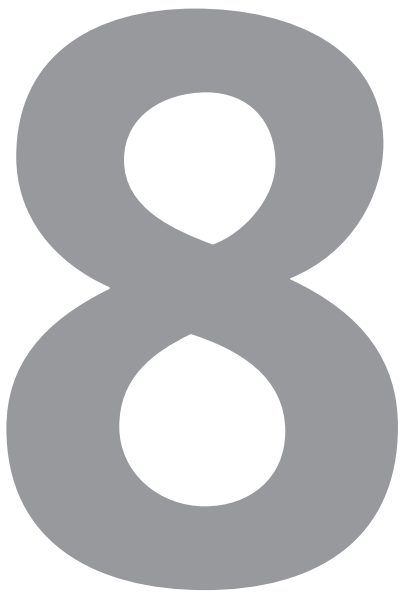

\section{Carla Pinto}




\subsection{CONTEXTO}

Nesta lição será abordado o suporte básico de vida pediátrico, incluindo a utilização do desfibrilhador automático externo na criança e a abordagem da obstrução da via aérea por corpo estranho ou sufocação e parte do suporte avançado de vida pediátrico, segundo as orientações do European Resuscitation Council (ERC) de 2015.

Será considerado lactente quando a idade for inferior a um ano, criança se idade entre um ano e o início da puberdade e adolescente após o início da puberdade. Nos adolescentes podem-se aplicar as guidelines dos adultos.

\subsection{DESCRIÇÃO DO TEMA}

\subsubsection{Causas de paragem cardio-respiratória}

As causas de paragem cardio-respiratória na criança são diferentes das dos adultos devido a especificidades anatómicas, fisiológicas e patológicas que variam com a idade. A paragem cardíaca secundária é mais frequente na criança. O ritmo pré-terminal mais frequente é a bradicardia, seguido da assistolia ou atividade elétrica sem pulsos (AESP). Estes ritmos são habitualmente, consequência de uma hipoxia tecidular grave que leva a disfunção miocárdica, que pode resultar de uma insuficiência respiratória com oxigenação inadequada ou de uma hipotensão grave, por insuficiência circulatória. Inicialmente são ativadas respostas fisiológicas de adaptação ou compensação para proteger da hipóxia o coração e o cérebro. No entanto, com a progressão da lesão ou doença subjacente, o organismo deixa de conseguir manter estas respostas. À medida que a situação da criança se agrava a insuficiência respiratória e circulatória associam-se, conduzindo a falência e posteriormente paragem cardio-respiratória.

A paragem cardíaca primária, por arritmia, como a fibrilação ventricular (FV) ou a taquicardia ventricular (TV) sem pulso, é mais frequente em adultos. O início é súbito e imprevisível, refletindo doença cardíaca intrínseca. É necessária desfibrilhação imediata. Por cada minuto que esta medida é atrasada, o número de casos com retorno da circulação espontânea diminui cerca de $10 \%$. O prognóstico após reanimação de uma paragem cardio-respiratória é habitualmente grave, principalmente se a paragem for prolongada. É essencial reconhecer os eventos que precedem a paragem e atuar de forma precoce e eficaz. A identificação e reanimação de uma criança em paragem respiratória, mas ainda com circulação espontânea, resultam numa sobrevida a longo prazo sem sequelas neurológicas de 50 a $70 \%$, sendo esta francamente reduzida (inferior a 15\%) nas crianças em paragem cardio-respiratória com assistolia. É fundamental, o reconhecimento das situações de risco, de forma a atuar de um modo estruturado e enérgico para evitar a degradação clínica.

\subsubsection{Características das crianças}

As especificidades anatómicas e fisiológicas dos lactentes e crianças face aos adultos são responsáveis pelas diferenças na etiologia da paragem cardio-respiratória. Estas especificidades ocorrem a nível da via aérea $(A)$, respiração/breathing 
(B), circulação (C), neurológico/disability (D) e na exposição/ambiente (E). Na via aérea (A): a cabeça dos lactentes é grande, proporcionalmente ao corpo, o que associado a um occipital mais proeminente tende a provocar flexão do pescoço em decúbito dorsal, causando obstrução; a face e a boca de um lactente são pequenas e a língua relativamente grande obstruindo facilmente a via aérea numa criança inconsciente; o lactente é um respirador nasal preferencial durante os primeiros seis meses de vida, pelo que qualquer obstrução nasal por infeção respiratória com secreções ou anatómica como a atresia das coanas pode aumentar o esforço respiratório e levar a insuficiência respiratória; em crianças com menos de oito anos, a laringe é afunilada, com a secção mais estreita a nível da cartilagem cricoide, pelo que, nas situações de obstrução da via aérea por corpo estranho (OVACE) não devem ser tentadas manobras de remoção do corpo estranho pois este pode encravar na zona mais estreita da laringe; de acordo com a lei de Poiseuille, a resistência é inversamente proporcional à quarta potência do raio, assim nos lactentes reflete-se ainda mais a redução do diâmetro da via aérea (i.e. secreções) com grande impacto na resistência ao fluxo de ar para os pulmões. A respiração (B) avaliada através da mecânica respiratória também se modifica com a idade. No lactente, as costelas são menos rígidas, mais flexíveis e os músculos intercostais são relativamente fracos e ineficazes comparativamente ao diafragma. Este é o principal músculo respiratório do lactente; obstáculos mecânicos à contração do diafragma, de origem abdominal (distensão gástrica, oclusão intestinal, pneumoperitoneu) ou torácica (hiperinsuflação por bronquiolite, asma ou corpo estranho) podem levar a ventilação ineficaz. Na criança maior, os músculos intercostais estão mais desenvolvidos e contribuem mais para a mecânica ventilatória. As costelas estão mais ossificadas e agem como um suporte rígido, menos suscetível de colapsar em situações de esforço respiratório marcado. $\mathrm{Na}$ insuficiência respiratória em crianças mais pequenas pode haver retrações (tiragem) significativas a nível esternal e intercostal, pela maior colapsabilidade da grelha costal. Esta retração é menos evidente em crianças mais velhas mas se estiver presente, indica grave compromisso respiratório. A frequência respiratória é mais elevada em lactentes e crianças pequenas, como resposta a taxas metabólica e de consumo de oxigénio superiores. Relativamente à circulação (C) também há especificidades: a volémia do recém-nascido é de $80 \mathrm{~mL} / \mathrm{kg}$, diminuindo com a idade até 60 a $70 \mathrm{~mL} / \mathrm{kg}$ no adulto. Num recém-nascido de três kilos, a volémia é de $240 \mathrm{~mL}$ e num lactente de seis meses, com seis kilos, será à volta de $480 \mathrm{~mL}$. Estes valores provam como as crianças são suscetíveis à perda de fluidos, dada a sua reduzida volémia.

A frequência cardíaca pelos mesmos motivos também é mais elevada nas crianças. Já a pressão arterial é mais baixa nas crianças pequenas em relação às mais velhas e adolescentes. Uma das dificuldades em lidar com as crianças mais pequenas do ponto de vista Neurológico (D) é a comunicação. Deve-se lidar com as crianças doentes de forma empática e adequada à idade, pois é natural que se sintam assustadas, particularmente se estão em ambiente estranho. É importante explicar a situação à criança de forma clara e percetível e deve permitir-se aos pais ficar junto aos seus filhos, mesmo durante a prestação de cuidados mais complexos ou avançados. 
$\mathrm{Na}$ avaliação neurológica existe uma escala de coma de Glasgow modificada para uso em crianças abaixo dos 5 anos, dada a sua imaturidade em termos de comunicação. Uma avaliação rápida do estado neurológico e de consciência da criança pode ser efetuada na primeira abordagem usando o método AVDS (Alerta, Voz, Dor e Sem resposta) em conjunto com o diâmetro e reação pupilares e a postura da criança. Esta escala avalia a resposta da criança a estímulos. É importante garantir um exame completo da criança na avaliação do item exposição - ambiente (E). As roupas devem ser removidas, tendo o cuidado de proteger do frio, e respeitar a intimidade. Devem procurar-se indícios que permitam entender a doença/problema. Os dados da história são colhidos recorrendo à mnemónica AMPLE (Alergia, Medicamentos, história médica Prévia, Last meal, Eventos e ambiente).

O peso é importante porque os fármacos para crianças são prescritos com base no seu peso corporal. Numa situação de emergência não há tempo ou condições para pesar a criança. A fórmula seguinte, aplicável entre um e os dez anos de idade, dá-nos um peso aproximado em função da idade da criança: Peso $(\mathbf{k g})=\mathbf{2 x}$ [idade em anos +4].

\subsubsection{Reconhecimento da criança gravemente doente}

O reconhecimento e a abordagem precoce da criança gravemente doente evitam a progressão para uma situação de paragem cardio-respiratória, reduzindo a morbilidade e mortalidade. A identificação de uma criança gravemente doente e as intervenções subsequentes devem seguir os princípios $\mathrm{ABCDE}$.
Uma função respiratória normal implica uma oxigenação e ventilação adequadas através da membrana alvéolo-capilar. A ventilação-minuto, dependente do volume corrente (volume de ar inspirado num ciclo respiratório) e da frequência respiratória (FR), é o principal determinante da remoção de dióxido de carbono. Uma respiração normal necessita de um esforço mínimo. A frequência respiratória varia com a idade, Quadro 1. O volume corrente espontâneo mantem-se em cerca de sete a nove $\mathrm{mL} / \mathrm{kg}$ durante toda a vida. Pode ser avaliado qualitativamente através da auscultação pulmonar, procurando ouvir a entrada de ar em todas as zonas pulmonares e observando a expansão torácica com a respiração.

Do ponto de vista fisiológico, a insuficiência respiratória é habitualmente definida como: incapacidade do sistema respiratório manter uma pressão parcial de oxigénio - $\mathrm{PaO}_{2}$ superior a 60 $\mathrm{mmHg}$ com uma fração de oxigénio inspirado - $\mathrm{FiO}_{2}$ de 21\% (ar ambiente); correspondendo aproximadamente a uma saturação periférica de oxigénio - $\mathrm{SpO}_{2}$ de $90 \%$ ou uma pressão parcial de dióxido de carbono - $\mathrm{PaCO}_{2}$ inferior a 60 $\mathrm{mmHg}$. Esta definição implica a realização de uma gasometria arterial que pode ser difícil de obter e pouco fiável nas crianças. Para além disso, uma criança com dificuldade respiratória pode conseguir manter os gases do sangue dentro de limites relativamente normais, à custa de um aumento do esforço respiratório. Quando os mecanismos de compensação (aumento da frequência respiratória, cardíaca e utilização dos músculos acessórios) falham, a deterioração pode ser muito rápida e a paragem cardio-respiratória iminente tem que ser antecipada. Para haver um bom fluxo de ar e uma ventilação-minuto adequada, a via aérea 


\begin{tabular}{|l|l|l|l|}
\hline Idade & $\begin{array}{l}\text { FR normal } \\
\text { (limite superior) }\end{array}$ & $\begin{array}{l}\text { FC normal } \\
\text { (limite superior) }\end{array}$ & $\begin{array}{l}\text { PA sist. normal } \\
\text { (limite inferior) }\end{array}$ \\
\hline 1 mês & $35(55)$ & $120(175)$ & $60(50)$ \\
\hline 1 ano & $30(40)$ & $110(170)$ & $80(70)$ \\
\hline 2 anos & $25(30)$ & $100(160)$ & $\begin{array}{l}90+2 * \text { idade } \\
(70+2 * \text { idade })\end{array}$ \\
\hline 6 anos & $20(25)$ & $90(130)$ & $\begin{array}{l}90+2 * \text { idade } \\
(70+2 * \text { idade })\end{array}$ \\
\hline 12 anos & $15(20)$ & $80(100)$ & $120(90)$ \\
\hline
\end{tabular}

๑ European Ressuscitation Council - www.erc.edu - 2017_NGL_008

Quadro 1. Valores normais de Frequência Respiratória, Frequência Cardíaca e Pressão Arterial em lactentes e crianças (valores médios, com os superiores e inferiores entre parênteses).

(A) tem que estar desobstruída e estável. Se a via aérea está em risco e instável, pode ficar obstruída (i.e. numa criança inconsciente em respiração espontânea, a queda da língua pode obstruir a via aérea). A entrada de ar deve ser avaliada observando os movimentos respiratórios e torácicos, ouvindo os sons respiratórios e ruídos junto ao nariz e boca (ou por auscultação) e sentindo o movimento de ar junto ao nariz e boca.

As crianças com dificuldade respiratória procuram posições que otimizem a capacidade respiratória. Na obstrução da via aérea superior adotam muitas vezes uma posição de extensão do pescoço, para melhorar a permeabilidade da via aérea. Noutras situações, muitas vezes sentam-se inclinadas para a frente e apoiadas nos braços. Esta posição melhora a utilização de músculos acessórios. Deve permitir-se à criança adotar a posição mais confortável e/ou melhor para a permeabilização da via aérea.
Na respiração (B) deve ser avaliada a frequência respiratória, o trabalho respiratório (tiragem, utilização dos músculos acessórios, adejo nasal, balanceio da cabeça e contração dos músculos da parede anterior do tórax), a eficácia da respiração através da estimativa do volume corrente pela expansão torácica, auscultação e deteção de ruídos adicionais, a oxigenação (cianose central ou palidez; $\mathrm{SpO}_{2}$ ) e os efeitos da insuficiência respiratória noutros órgãos (coração: aumento da frequência cardíaca; cérebro: alteração do estado de consciência; pele: má perfusão periférica). Constituem sinais de alarme: a depressão do estado de consciência, a hipotonia, a redução do esforço respiratório, a cianose ou palidez extrema - apesar de oxigénio suplementar, e a sudorese.

Num lactente, a taquipneia pode ser o primeiro sinal de insuficiência respiratória. Uma queda súbita da frequência respiratória numa criança com doença aguda é um achado muito 
significativo de gravidade e pode ser um evento pré-terminal. O esforço respiratório é geralmente proporcional à gravidade da insuficiência respiratória, exceto na depressão respiratória central, nas doenças neuromusculares e na exaustão. A tiragem é facilmente observada no lactente e criança pequena pela elevada compliance da caixa torácica, figura 1. Nas crianças com mais de cinco anos, a tiragem revela um compromisso importante da função respiratória.

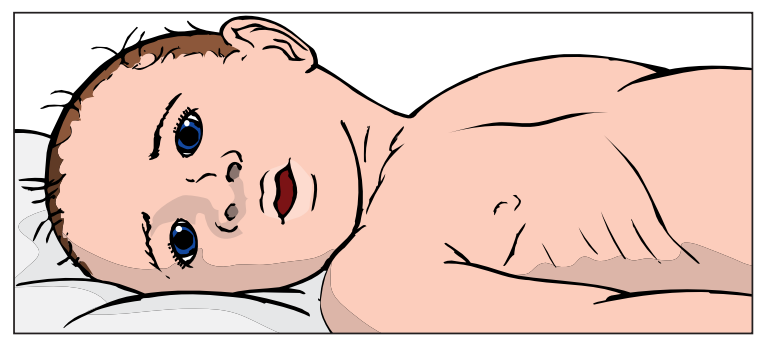

(c) European Ressuscitation Council - www.erc.edu - 2017_NGL_008

Figura 1. Insuficiência respiratória descompensada numa criança com dificuldade respiratória (tiragem sub e intercostal, xifoideia e adejo nasal) e diminuição da interação com o meio.

Quando o trabalho respiratório aumenta, o esternocleidomastoideu pode ser usado como músculo acessório. Esta adaptação no lactente pode originar um movimento de balanceio da cabeça para cima e para baixo, diminuindo a eficácia da ventilação, sendo portanto um sinal de gravidade. A respiração paradoxal consiste num movimento de expansão do abdómen e retração da parede anterior do tórax durante a inspiração provocada pela contração do diafragma. Este tipo de respiração também é ineficaz, porque há redução do volume corrente com aumento do esforço muscular. O adejo nasal é muitas vezes observado em crianças com esforço respiratório.
A deteção de ruídos respiratórios anómalos e o momento do ciclo em que surgem, indicam o local da obstrução. Um ruido inspiratório rude e mais ou menos agudo (estridor) é característico de uma obstrução alta da via aérea (extra-torácica). O estridor bifásico (inspiratório e expiratório) indica uma obstrução a nível superior da traqueia. Quando o local da obstrução é mais distal (nível inferior da traqueia) o ruido é expiratório. Os sibilos (ruídos expiratórios prolongados, audíveis na auscultação) indicam estreitamento das vias aéreas inferiores, normalmente a nível brônquico ou bronquiolar (intra-torácico). Uma diminuição do ruido pode indicar uma obstrução completa ou exaustão da criança. O gemido surge principalmente no recém-nascido, mas por vezes também no lactente e criança pequena. É um som que resulta do movimento do ar exalado contra uma glote que parcialmente fechou, numa tentativa de gerar uma pressão positiva no final da expiração, de modo a preservar a capacidade residual funcional, impedindo o colapso alveolar.

O choque ocorre quando o fluxo sanguíneo e a entrega de nutrientes aos tecidos não são suficientes para as necessidades metabólicas. A entrega inadequada dos substratos metabólicos (i.e. oxigénio, glicose) e a falha na remoção dos metabolitos celulares desencadeiam o metabolismo anaeróbio com acumulação de ácido láctico e lesão celular. O choque pode surgir com débito cardíaco ou pressão arterial aumentados, normais ou diminuídos, figura 2. Pode ser compensado ou descompensado. O choque compensado surge na fase inicial, sem hipotensão. Apesar da pressão arterial ser normal, observam-se sinais de falência circulatória, taquicardia, má perfusão cutânea, 


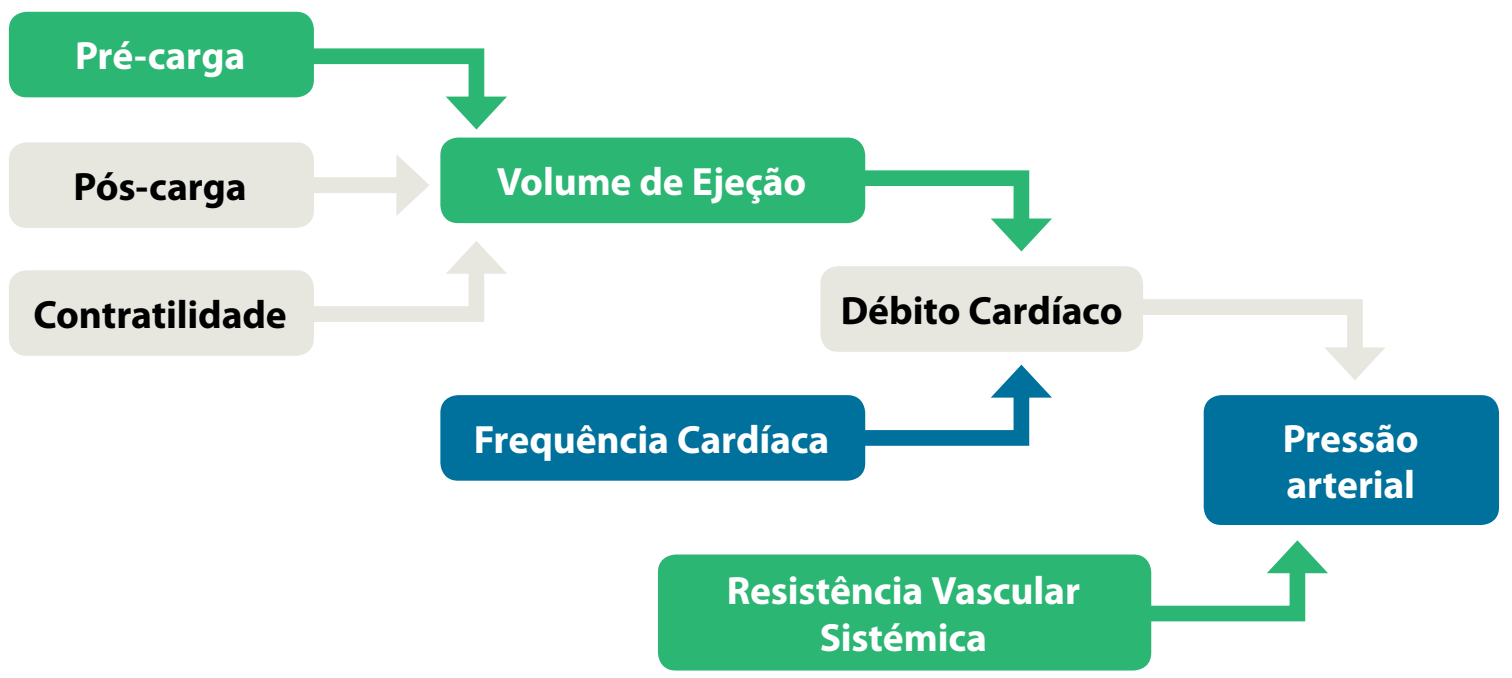

Relações entre variáveis que afetam o débito cardíaco e variáveis que afetam a pressão arterial Variáveis mensuráveis diretamente Variáveis avaliadas clinicamente

Figura 2. Parâmetros cardio-vasculares e suas relações.

pulsos periféricos fracos, taquipneia e oligúria. O choque descompensado está presente quando surge hipotensão e compromisso da perfusão dos órgãos vitais (coração, cérebro).

No reconhecimento da criança com insuficiência circulatória ou choque é necessário avaliar a frequência cardíaca (FC), a pressão arterial, Quadro 1, o volume do pulso central e periférico, a perfusão periférica através do tempo de reperfusão capilar, a pré-carga (ingurgitamento das veias jugulares, fervores pulmonares e hepatomegália; estes traduzem aumento da pré-carga e permitem diferenciar o choque cardiogénico dos outros) e os efeitos noutros órgãos (respiratório: aumento da frequência respiratória; cérebro: alteração do estado de consciência; rins: oligúria).

As crianças têm uma reserva cardíaca limitada; aumentam o débito cardíaco mais à custa de uma elevação da frequência cardíaca do que do volume sistólico. Os mecanismos compensatórios para restabelecer o débito cardíaco quando há diminuição do volume vascular são: taquicardia, vasoconstrição e aumento da contratilidade do miocárdio. O volume de ejeção diminui com a hipovolémia. Inicialmente, há um aumento da frequência cardíaca e da resistência vascular periférica para manter a pressão arterial dentro dos limites do normal. Quando os mecanismos de compensação faIham, surge a descompensação com hipotensão. 


\section{A taquicardia é mantida até haver depleção das catecolaminas estimulantes do miocár-}

dio. A hipotensão aparece particularmente tarde no choque, sendo um sinal de descompensação fisiológica e deve ser tratada vigorosamente, porque a falência cardio-respiratória com paragem pode estar iminente. O volume de ejeção pode ser avaliado pela palpação da amplitude do pulso. À medida que o volume de ejeção diminui, a amplitude do pulso também reduz. A amplitude dos pulsos periféricos (i.e. radial) diminui mais rapidamente do que a dos pulsos arteriais centrais. A comparação entre os pulsos periféricos e os centrais pode ser útil.

A diminuição dos pulsos centrais é um sinal de alarme de paragem cardio-respiratória iminente. O tempo de reperfusão capilar é utilizado para avaliar a perfusão; se estiver prolongado, indica vasoconstrição periférica, constituindo um sinal precoce de choque. Avalia-se fazendo pressão sobre uma área de pele durante cinco segundos (i.e. esterno). Depois de libertar a pressão, a cor deve voltar ao normal em menos de dois segundos. O local de avaliação deve estar ao nível do coração (ou ligeiramente acima) para evitar a estase venosa.

Os sinais de falência cardio-respiratória iminente, em que é necessário uma intervenção terapêutica imediata e eficaz são: comportamento pouco habitual, coma ou alteração da consciência, exaustão por dificuldade respiratória, cianose, taquipneia (FR >60 cpm), FC >180 bpm ou FC $<80$ bpm antes de um ano de idade, FC >160 bpm ou FC <60 bpm depois de um ano de idade, febre com exantema purpúrico, trauma grave ou queimaduras afetando cerca de $15 \%$ da superfície corporal e convulsões.
A abordagem da criança gravemente doente passa pela colocação imediata de uma máscara de oxigénio de alta concentração e acesso venoso, detalhados à frente.

\subsubsection{Suporte básico de vida pediátrico}

O suporte básico de vida pediátrico (SBV) consiste na aplicação de manobras e competências que, sem a utilização de adjuvantes técnicos, permitem o reconhecimento e intervenção numa criança em paragem cardíaca ou respiratória e possibilita "ganhar tempo" até a criança poder receber tratamento mais diferenciado. Deve ser iniciado o mais rapidamente possível. O principal objetivo é conseguir oxigenação suficiente para proteger o cérebro e os outros órgãos vitais. Apesar de pouco frequente, a paragem cardíaca primária, FV ou TV sem pulso, ocorre ocasionalmente em crianças. Se esta for uma situação provável, como no colapso súbito testemunhado de uma criança com uma doença cardíaca conhecida, o prognóstico dependerá de desfibrilhação precoce. Neste caso, é preferível, para um reanimador sozinho, ativar o serviço de emergência médica (SEM) antes de iniciar o SBV, e utilizar um desfibrilhador automático externo (DAE) se disponível. No entanto, para a maioria das crianças em paragem cardio-respiratória, a sequência de atitudes recomendada baseia-se em dois factos fundamentais:

1. A maioria das paragens em crianças resulta da hipóxia e a prioridade é a permeabilização da via aérea e o fornecimento imediato de oxigénio (insuflações com ar expirado). 


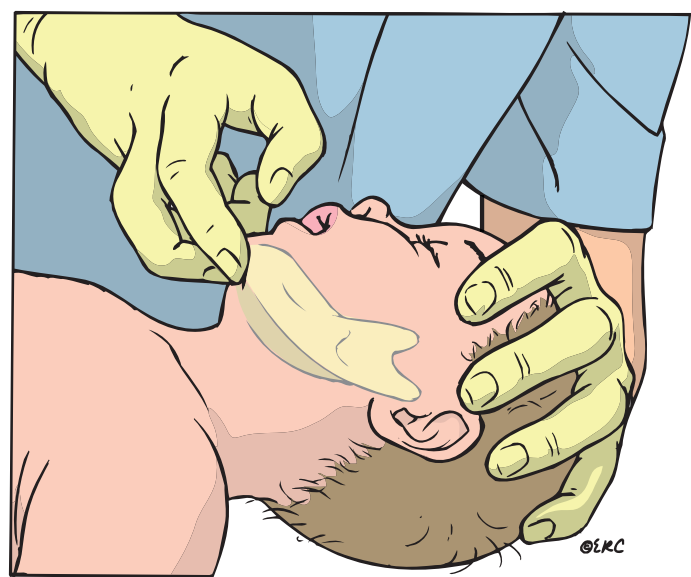

C European Ressuscitation Council - www.erc.edu - 2017_NGL_008

Figura 3. Cabeça na posição neutra e elevação do queixo no lactente.

2. A arritmia mais frequente nas paragens em crianças é a bradicardia grave que evolui para assistolia. Assim, o SBV eficaz é mais importante que o acesso rápido a um desfibrilhador.

No caso de estar presente só um reanimador, é recomendado iniciar e manter o SBV durante um minuto antes de ponderar abandonar a criança para chamar ajuda. Se existe mais que um reanimador, um deles deve procurar ajuda imediatamente, ativando o SEM, enquanto o outro inicia SBV. O SBV deve ser executado segundo a ordem - SSS, ABC, R: Safety (segurança); Stimulate (estimular); Shout for assistance (chamar ajuda); Airway (via aérea); Breathing (respiração); Circulation (circulação); Reassess (reavaliar).

A ordem das ações é muito importante porque se uma manobra não for bem executada, a eficácia da seguinte pode ficar comprometida. Em todas as emergências é essencial avaliar

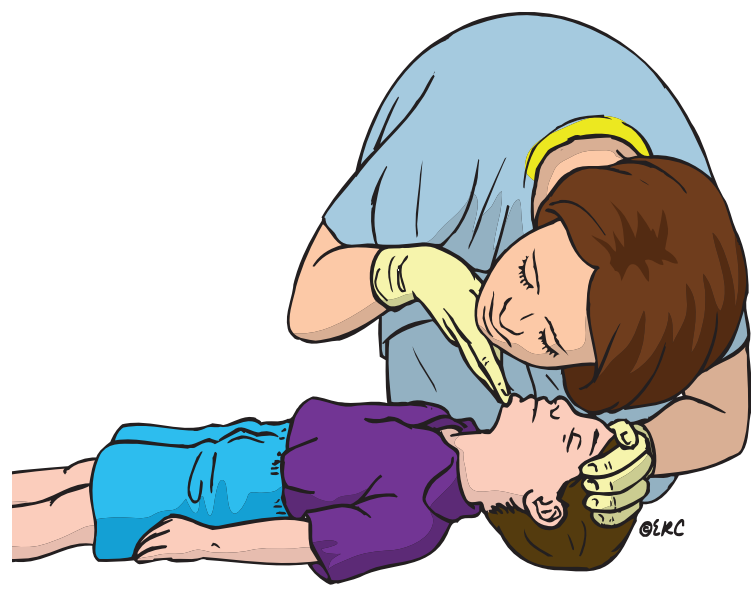

๑ European Ressuscitation Council - www.erc.edu - 2017_NGL_008

Figura 4. Extensão da cabeça e elevação do queixo na criança pequena.

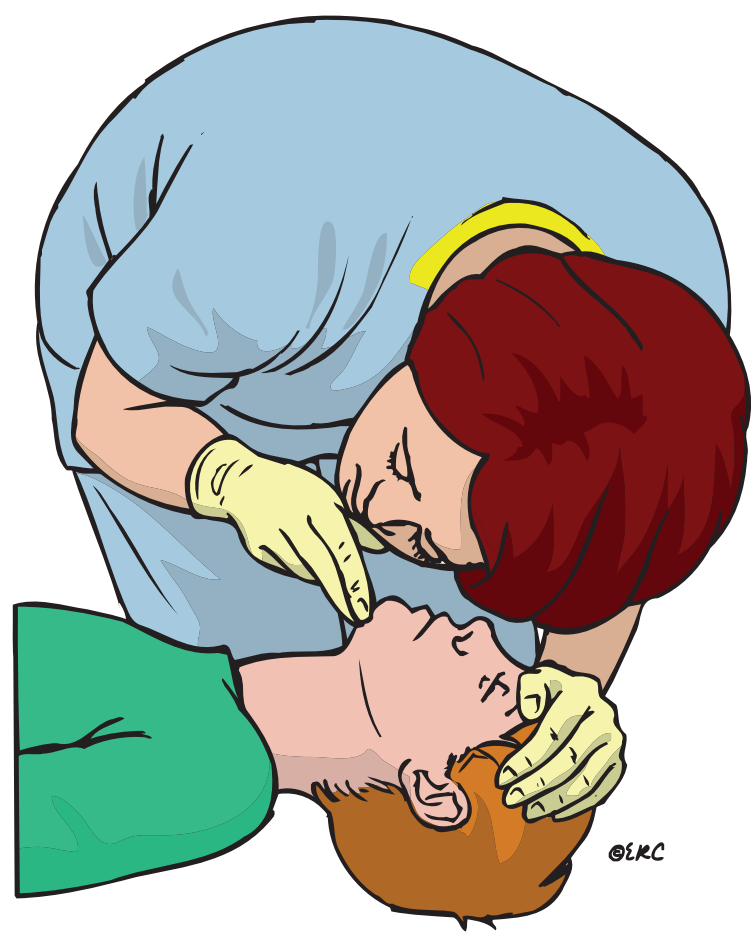

C European Ressuscitation Council - www.erc.edu - 2017_NGL_008

Figura 5. Extensão da cabeça e elevação do queixo na criança maior. 


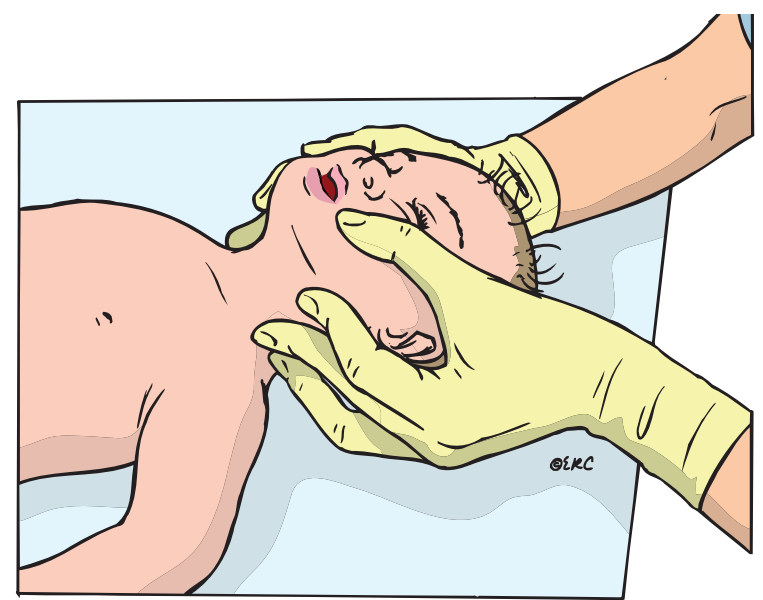

๑) European Ressuscitation Council - www.erc.edu - 2017_NGL_008

Figura 6. Manobra de subluxação da mandibula.

rapidamente a situação e garantir primeiro a segurança dos reanimadores e depois a da criança. $\mathrm{O}$ modo adequado de o fazer é estabilizar a cabeça, colocando uma mão na fronte e utilizar a outra mão para abanar o braço da criança ou puxar o cabelo. Ao mesmo tempo, deve chamar-se o nome da criança em voz alta e dizer-Ihe "Acorda!" ou perguntar-lhe "Estás bem?". Nunca se deve sacudir a criança. Se não houver resposta, deve-se iniciar SBV imediatamente. Se outra pessoa estiver disponível, deve ativar o SEM (número europeu universal - 112).

\section{Permeabilizar a via aérea (A)}

A permeabilização da via aérea pode ser efetuada de dois modos: posicionamento da cabeça e subluxação da mandibula. Em lactentes, a cabeça deve ser colocada na posição neutra (eixo da orelha alinhado com o eixo do tronco - figura 3). Na criança é necessário efetuar mais extensão da cabeça, figuras 4 e 5. A manobra de subluxação

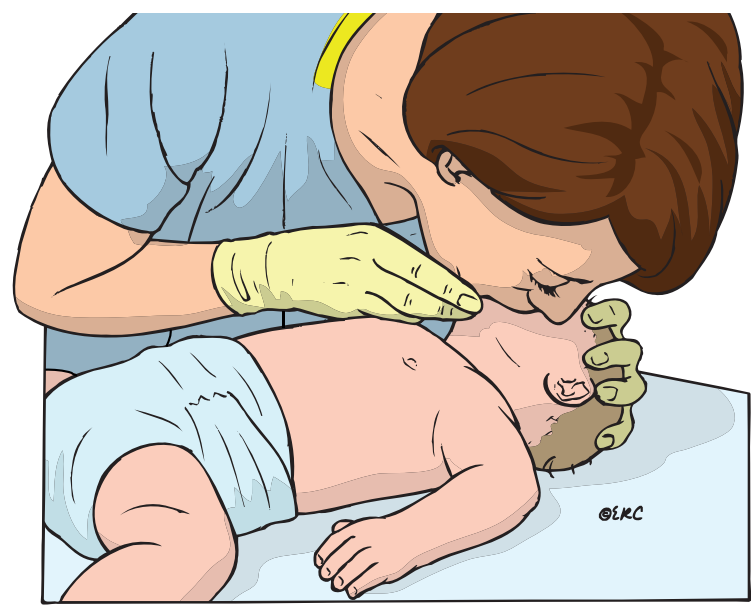

C European Ressuscitation Council - www.erc.edu - 2017_NGL_008

Figura 7. Insuflações iniciais no lactente, com a técnica boca a boca-nariz.

da mandíbula é utilizada para abertura da via aérea na criança quando é necessária imobilização da coluna cervical. O reanimador coloca as mãos nos dois lados da cabeça. As extremidades de dois ou três dedos de cada mão colocam-se debaixo dos ângulos da mandibula, elevando-a, com os polegares cuidadosamente apoiados nos malares, figura 6. Para maior estabilidade, os cotovelos do reanimador devem estar apoiados na superfície em que a criança esta deitada.

\section{Respiração (B)}

Após permeabilizar a via aérea é necessário, avaliar a eficácia da respiração espontânea, que deve demorar menos de dez segundos, vendo os movimentos torácicos e abdominais, ouvindo sons e ruídos respiratórios junto à boca e nariz e sentindo o movimento de ar junto à boca e nariz. Se a criança não respira eficazmente ou tem apenas respiração agónica, o reanimador deve efetuar cinco insuflações iniciais com ar expirado, mantendo a via 


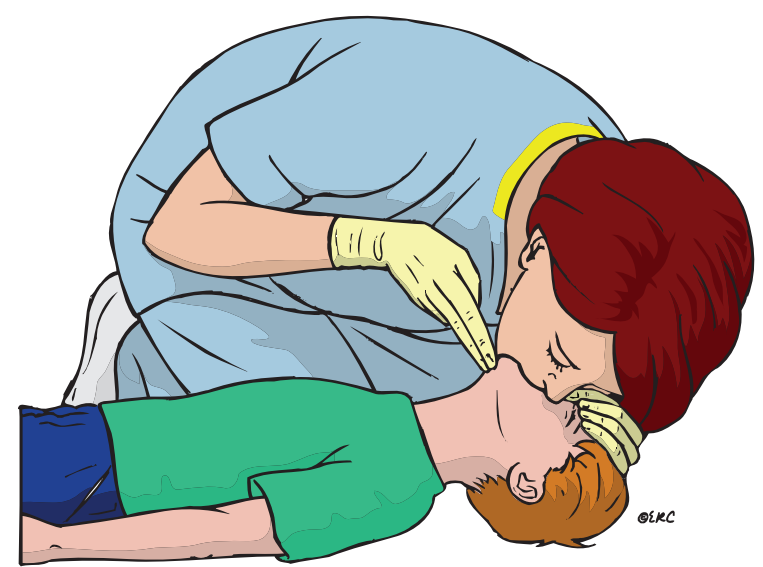

๑ European Ressuscitation Council - www.erc.edu - 2017_NGL_008

Figura 8. Insuflações iniciais na criança com a técnica boca-a-boca.

aérea patente. Cada insuflação deve ser lenta (cerca de um segundo). O reanimador pode efetuar uma inspiração profunda entre cada duas insuflações, para otimizar $\mathrm{O}_{2}$ e minimizar o $\mathrm{CO}_{2}$ que administra à criança. As insuflações são efetuadas através das técnicas boca a boca-nariz e boca-a-boca. A primeira é recomendada em lactentes, figura 7. 0 reanimador coloca a sua boca em volta da boca e do nariz do lactente, criando uma boa selagem, e insufla. Na criança a insuflação é feita procedendo a uma boa selagem na boca, ocluindo o nariz para evitar a fuga de ar como ilustrado na figura 8.

A eficácia das insuflações iniciais avalia-se observando a elevação e descida do tórax. O reanimador deve adaptar a pressão e volume das insuflações às características da criança para garantir expansão torácica com cada insuflação.

\section{Circulação (C)}

Após as insuflações iniciais o reanimador deve avaliar se a criança tem circulação espontânea ou se

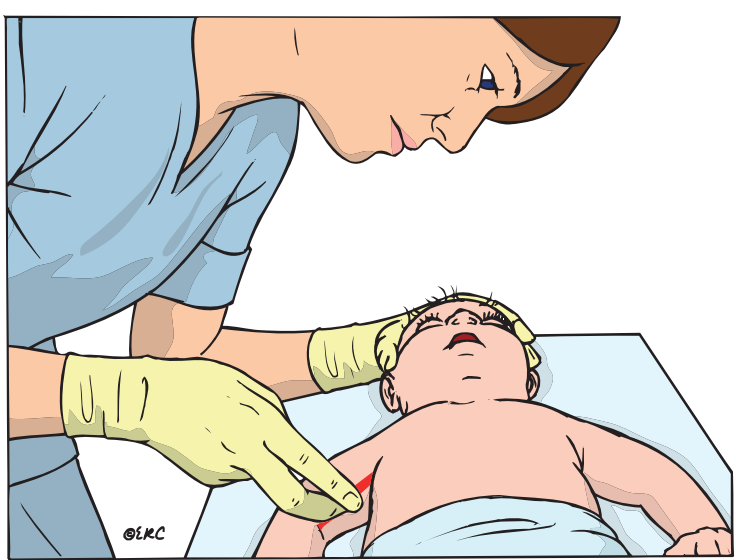

C European Ressuscitation Council - www.erc.edu - 2017_NGL_008

Figura 9. Palpação do pulso braquial e pesquisa de sinais de circulação no lactente.

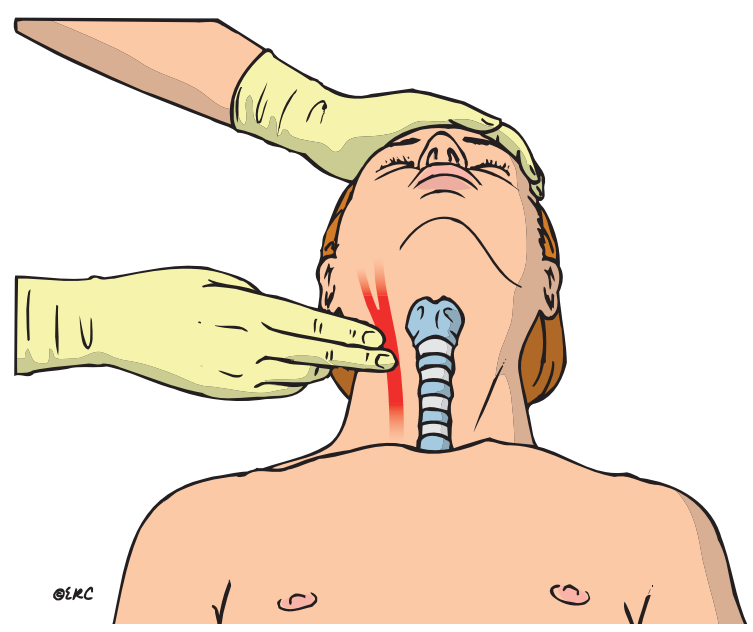

C European Ressuscitation Council - www.erc.edu - 2017_NGL_008

Figura 10. Palpação do pulso carotídeo na criança.

necessita de compressões torácicas. Deve-se observar se há sinais de circulação: movimento, tosse ou respiração normal ou palpar um pulso central. A palpação do pulso central, sobretudo para leigos, pode causar dúvidas por isso a decisão de continuar o SBV 


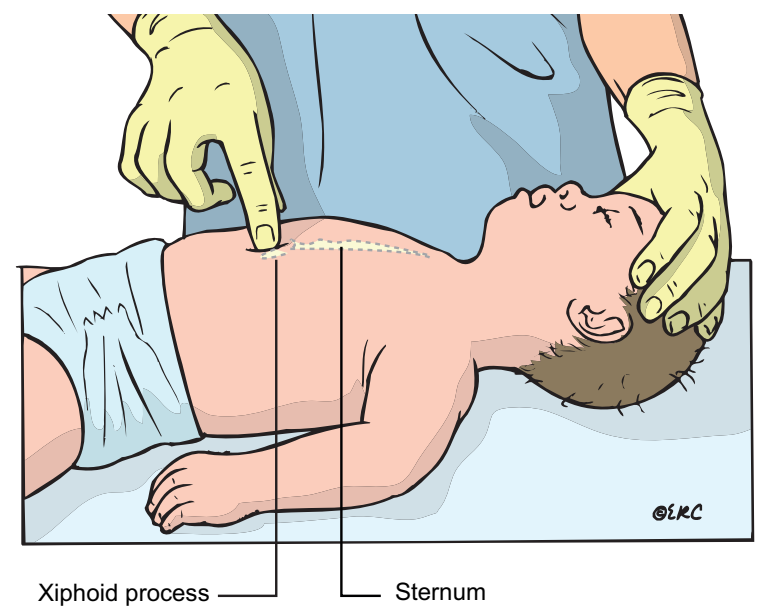

C European Ressuscitation Council - www.erc.edu - 2017_NGL_008

Figura 11. Localização do apêndice xifoide na junção das costelas inferiores. Adaptado de ERC

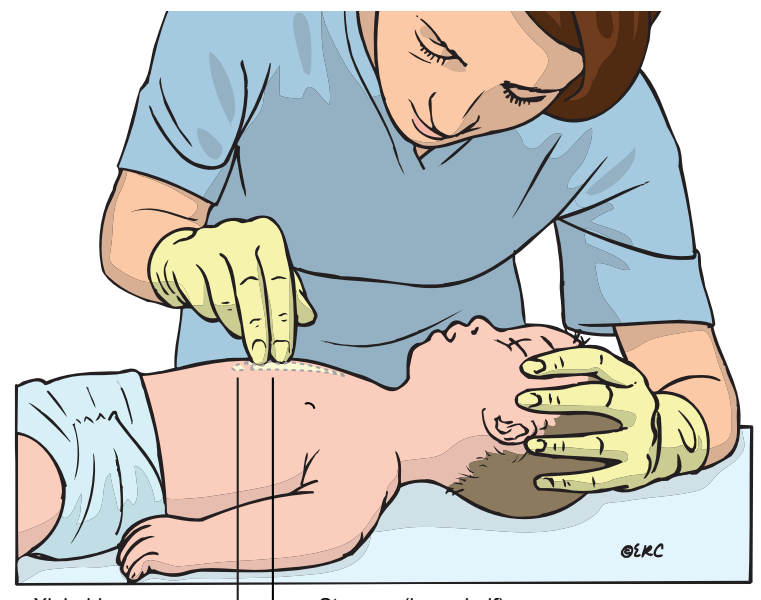

Xiphoid process $\square$ Sternum (lower half)

๑ European Ressuscitation Council - www.erc.edu - 2017_NGL_008

Figura 12. Compressões torácicas no lactente: técnica dos dois dedos.

é baseada nos sinais de circulação. Em lactentes, os locais recomendados para avaliação do pulso central são as artérias braquial ou femoral, figura 9. Nas crianças palpa-se a carótida, figura 10, ou a femoral. Se não há sinais de circulação, devem ser iniciadas

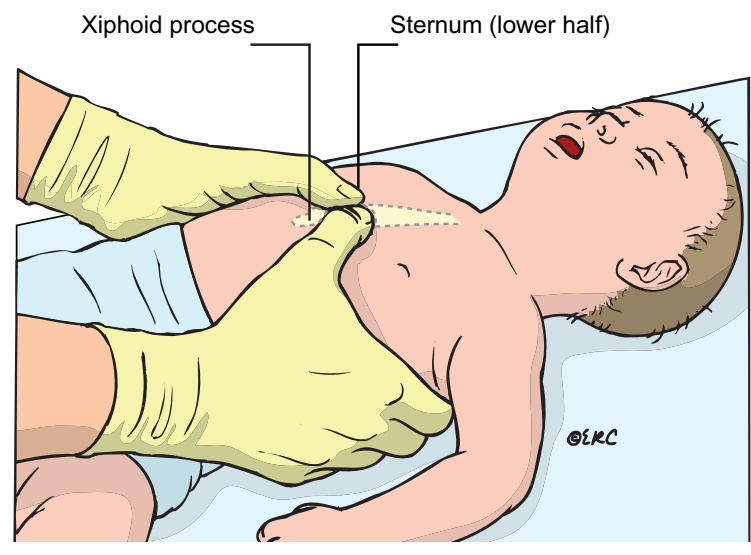

() European Ressuscitation Council - www.erc.edu - 2017_NGL_008

Figura 13. Compressões torácicas no lactente: técnica do abraço (dois polegares).

compressões torácicas, a menos que o reanimador tenha a CERTEZA de que consegue palpar um pulso central com frequência superior a 60 bpm.

O tempo máximo para avaliação dos sinais de circulação é de dez segundos. Se não há sinais de circulação devem ser iniciadas compressões torácicas. Estas são seriadas, rítmicas, exercidas sobre a parede torácica anterior para conseguir um fluxo sanguíneo suficiente para os órgãos vitais, numa tentativa de os manter viáveis, até ao retorno da circulação espontânea. Para serem executadas eficazmente, a criança deve ser colocada em decúbito dorsal numa superfície plana e dura, mantendo a cabeça numa posição que permita a patência da via aérea. A relação entre as compressões e as ventilações deve ser de 15:2, atingir uma frequência de compressões de 100 a 120 bpm, deprimir o tórax pelo menos um terço do seu diâmetro antero-posterior (quatro $\mathrm{cm}$ no lactente e cinco cm nas outras crianças) e todas as interrupções devem ser minimizadas. 
As compressões torácicas devem ser aplicadas sobre a metade inferior do esterno, cerca de um dedo acima do angulo onde as costelas inferiores se encontram com o apêndice xifoide, figura 11.

As compressões torácicas no lactente podem-se efetuar de duas formas: técnica dos dois dedos, figura 12, ou a técnica do abraço com os dois polegares, figura 13. A primeira é recomendada quando há um reanimador único. Este coloca dois dedos de uma mão sobre a metade inferior do esterno. Quando há dois reanimadores é aconselhado utilizar a técnica do abraço pois permite um melhor débito cardíaco, mas é muito pouco provável que um reanimador único, consiga executá-la de modo eficaz, fazendo insuflações corretas sequencialmente.

Na criança, o reanimador posiciona-se ao seu lado e coloca a base de uma mão diretamente no eixo longo da metade inferior do esterno. Os dedos devem ser afastados do tórax, de modo que só a base da mão exerça pressão. O reanimador posiciona-se com os ombros diretamente acima do tórax da criança, mantém os braços estendidos e usa o peso corporal para deprimir o tórax, figura 14 . $\mathrm{Na}$ criança maior deve ser utilizada uma segunda mão, colocada sobre a primeira com os dedos entrelaçados e afastados da parede torácica, figura 15.

As compressões torácicas adequadas devem produzir um pulso palpável durante o SBV. Após um minuto, parar brevemente para reavaliar a criança, procurando rapidamente sinais de circulação e garantindo que o SEM foi ativado. O SBV apenas deve parar quando: a criança apresenta sinais de circulação, outras pessoas se encarregam da reanimação ou o reanimador fica demasiado exausto para continuar.

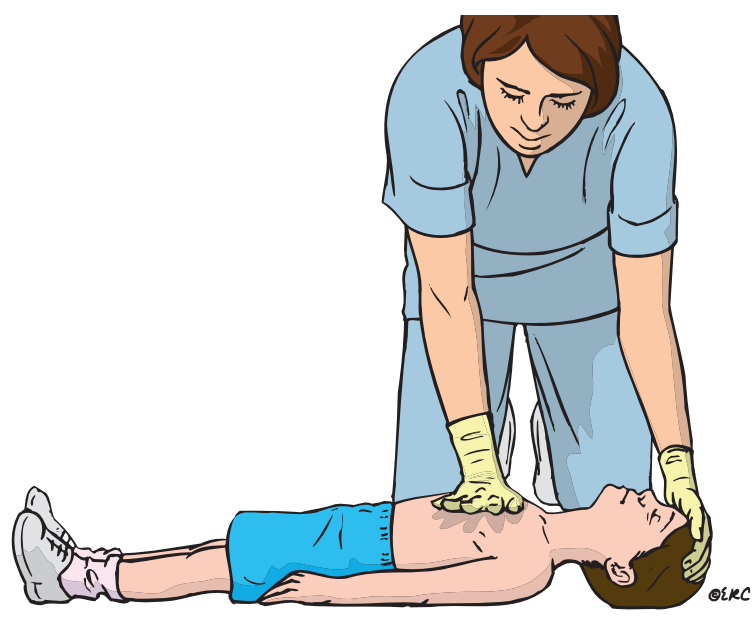

C European Ressuscitation Council - www.erc.edu - 2017_NGL_008

Figura 14. Compressões torácicas na criança pequena: técnica de uma mão.

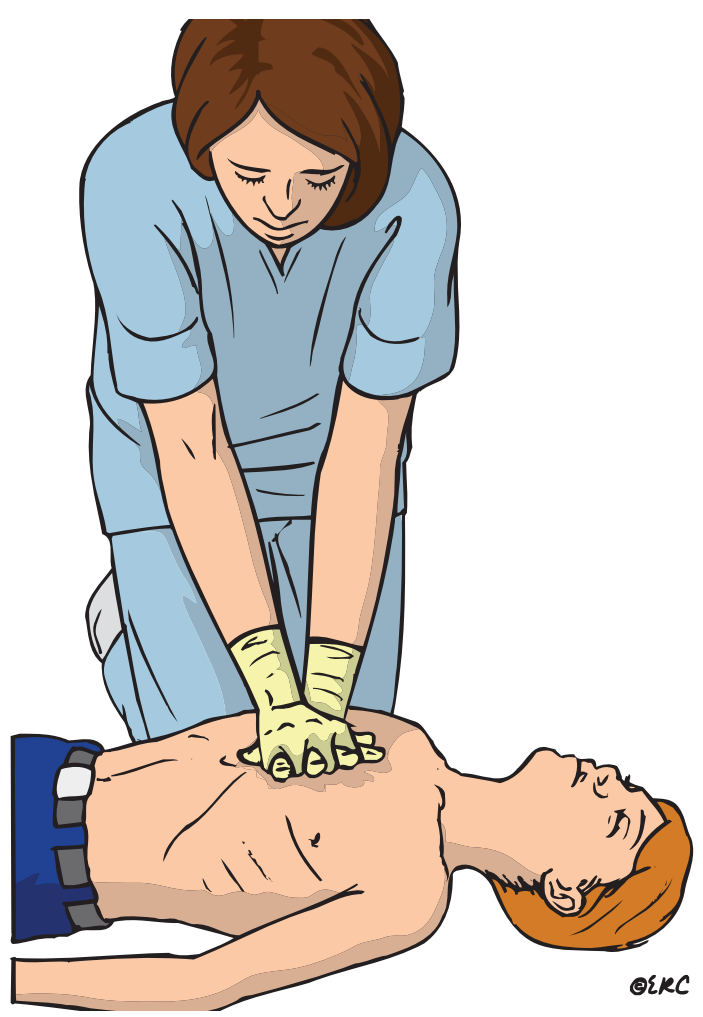

C European Ressuscitation Council - www.erc.edu - 2017_NGL_008

Figura 15. Compressões torácicas na criança maior: técnica de duas mãos. 


\section{Suporte Básico de Vida Pediátrico}
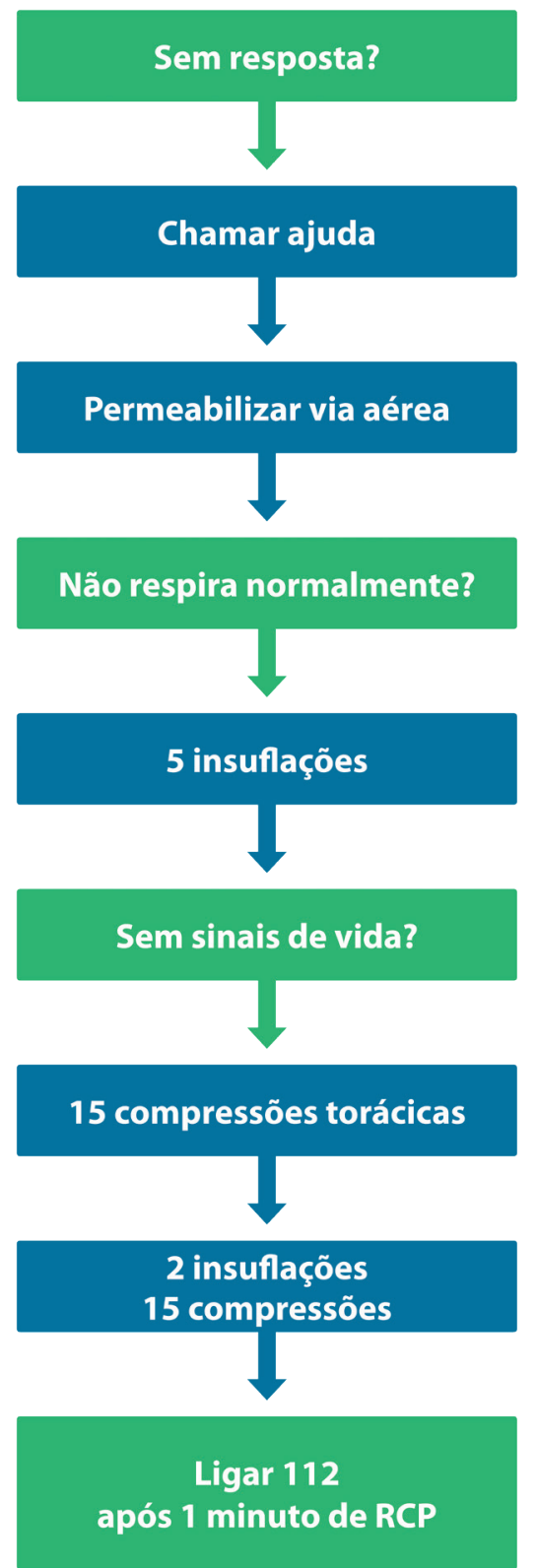

(C) European Ressuscitation Council - www.erc.edu - 2017_NGL_008

Figura 16. Algoritmo do Suporte Básico de Vida Pediátrico, RCP - Reanimação cardio-pulmonar.
Na figura 16 pode-se observar o algoritmo do SBV pediátrico.

Utilização de um desfibrilhador automático externo na criança

Estão disponíveis DAE's semi-automáticos e, ocasionalmente, totalmente automáticos. São dispositivos computorizados seguros e fiáveis, cada vez mais usados por leigos e profissionais de saúde. Um DAE analisa o eletrocardiograma (ECG) da vítima e determina se um choque para desfibrilhação está indicado, facilitando a sua administração. Nos modelos semi-automáticos, os mais frequentemente disponíveis, a administração do choque requer que o reanimador siga as instruções do aparelho e pressione o botão indicado. A principal vantagem do DAE é que reconhece ritmos desfibrilháveis específicos e, portanto, o choque pode ser administrado por um leigo. Se uma criança com mais de oito anos ou de $25 \mathrm{~kg}$

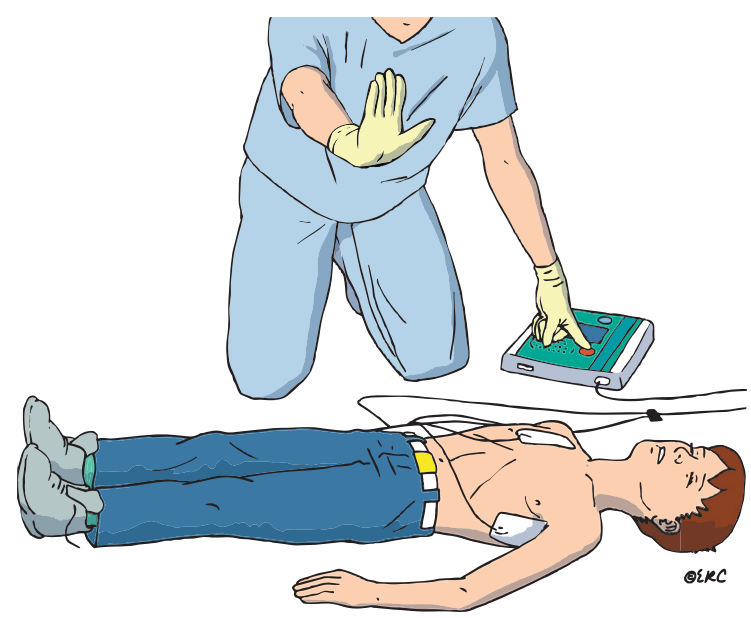

C European Ressuscitation Council - www.erc.edu - 2017_NGL_008

Figura 17. Utilização de um DAE na criança, após um minuto de SBV. 


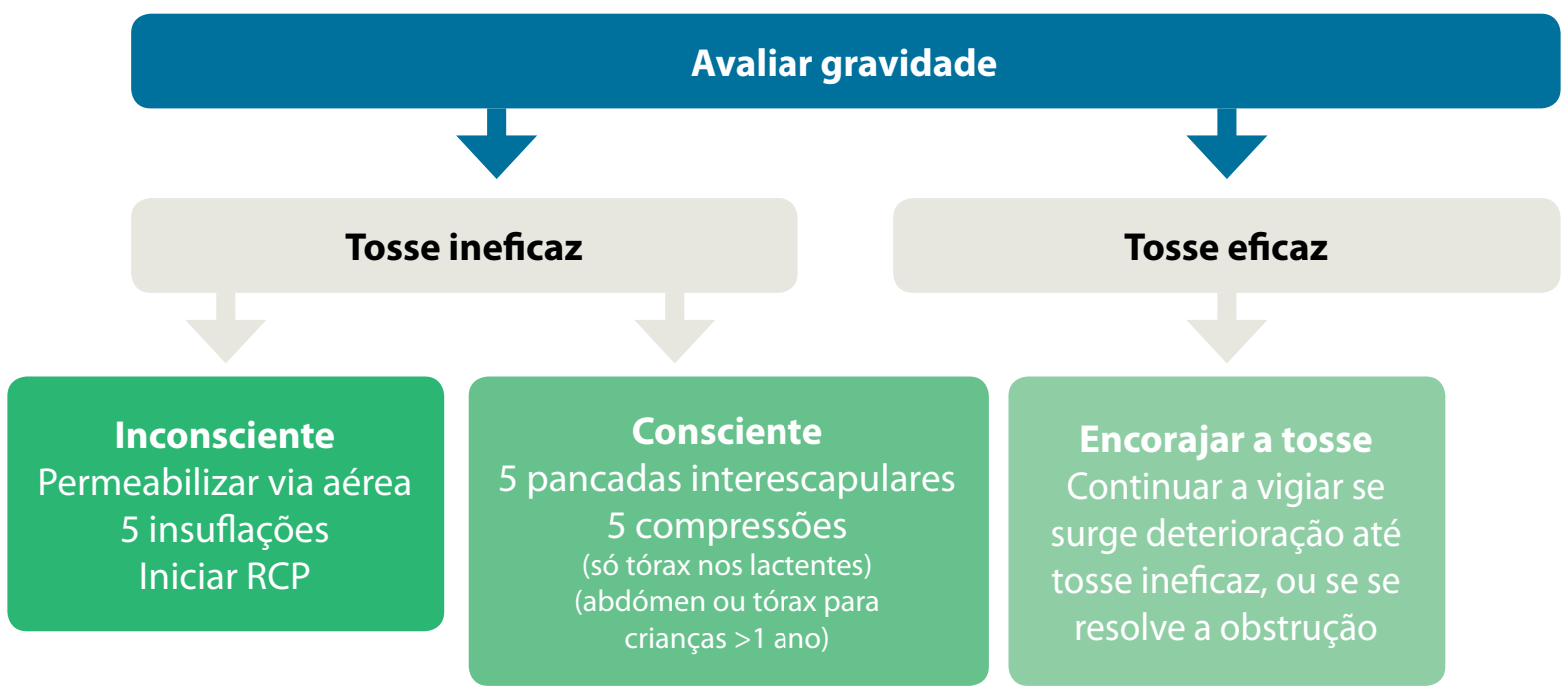

(C European Ressuscitation Council - www.erc.edu - 2017_NGL_008

Figura 18. Algoritmo da abordagem da sufocação pediátrica, RCP - Reanimação cardio-pulmonar.

necessita de desfibrilhação, um DAE standard pode ser usado. Para crianças com menos de oito anos ou de $25 \mathrm{~kg}$, deve ser idealmente usado um DAE com dispositivo atenuador. No entanto, se não estiver rapidamente disponível nem um desfibrilhador manual nem um com atenuador, um DAE standard pode ser usado em crianças com menos de oito anos. Os elétrodos dos DAE's são colocados: um à direita do esterno e outro na linha medio-axilar á esquerda. Na sequência de utilização de um DAE deve-se, figura 17:

1. garantir que o reanimador, a vítima e outros presentes estão em segurança;

2. iniciar SBV. Se há dois ou mais reanimadores, um continua com o SBV enquanto o outro chama ajuda e traz o DAE, se disponível. No caso de um reanimador único, deve chamar ajuda e trazer o DAE após um minuto de SBV (a menos que seja muito provável uma causa cardíaca). Em qualquer circunstância, não conectar o DAE antes de ter efetuado um minuto de SBV;

3. ligar o DAE e conectar os elétrodos (pediátricos se adequado). Se houver mais que um reanimador, continuar SBV;

4. seguir as indicações verbais e visuais do DAE;

5. assegurar que ninguém toca na vítima enquanto o DAE analisa o ritmo;

6. se estiver indicado choque, garantir que ninguém toca na vítima, pressionar o botão quando indicado, continuar SBV até serem detetados sinais de circulação;

7. se não estiver indicado um choque, retomar de imediato o SBV. Continuar a seguir as indicações do DAE;

8. continuar SBV até chegar ajuda, a vítima iniciar respiração normal, ou o reanimador ficar exausto. 


\begin{tabular}{l} 
Sinais gerais \\
Episódio testemunhado \\
Tosse ou engasgamento \\
\hline Início súbito, sem outros sinais de doença \\
\hline História recente de comer ou brincar com objetos pequenos \\
\hline Tosse eficaz \\
\hline Choro ou resposta verbal a perguntas \\
\hline Tosse bem audível \\
\hline Capaz de inspirar bem antes de tossir \\
Completamente alerta \\
\hline Tosse ineficaz \\
\hline Incapaz de vocalizar \\
\hline Tosse silenciosa, inaudível \\
Incapaz de respirar \\
Cianose \\
Nível de consciência diminuído
\end{tabular}

(C) European Ressuscitation Council - www.erc.edu - 2017_NGL_008

Quadro 2. Sinais de sufocação.

\section{Obstrução da via aérea por corpo estranho} ou sufocação

A maioria das situações de sufocação em lactentes e crianças ocorre enquanto brincam ou comem e, por isso, são muitas vezes observadas, o que permite que sejam tomadas rapidamente medidas se necessário. Deve suspeitar-se de sufocação se: o início é súbito, não há outros sinais de doença, há história recente de estar a comer ou a brincar com objetos pequenos imediatamente antes do início dos sintomas, quadro 2.

Na abordagem da sufocação, figura 18, é necessário avaliar a eficácia da tosse e o estado de consciência da criança.

Se a criança tosse eficazmente, não são necessárias quaisquer manobras. Deve-se encorajar a tosse e observar. Se a tosse é ineficaz, chamar ajuda e avaliar o nível de consciência. Se a criança está consciente, o reanimador deve aplicar pancadas interescapulares. Se as pancadas interescapulares não resolvem a obstrução, devem iniciar-se compressões torácicas no lactente ou abdominais na criança. Estas manobras simulam a tosse e aumentam a pressão intra-torácica para desalojar o corpo estranho. Na técnica das pancadas interescapulares no lactente, o reanimador deve apoia-lo em decúbito ventral com a cabeça mais baixa, para que a gravidade ajude na sua remoção. Se o reanimador está sentado ou ajoelhado deve conseguir apoiar o lactente de modo seguro ao seu colo. A cabeça deve ser apoiada colocando o polegar de uma mão num dos ângulos da mandibula e um ou dois dedos da outra mão no mesmo ponto do outro lado da mandibula. É importante ter-se cuidado para não exercer pressão nos tecidos moles debaixo da mandibula, o que poderia aumentar a obstrução da via aérea. Devem dar-se até cinco pancadas secas com a base de uma mão, nas costas, entre as omoplatas do lactente, figura 19. Na criança, as pancadas interescapulares também são mais eficazes se esta estiver com a cabeça para baixo. Se a criança é pequena, deve ser colocada ao colo do reanimador, como um lactente. Se isso não for possível, deve apoiar-se a criança numa posição inclinada para a frente e dar as pancadas interescapulares. Se as pancadas não removerem o corpo estranho, e a criança continuar consciente, o reanimador pode usar compressões torácicas no lactente, ou abdominais na criança. As compressões abdominais (manobra de Heimlich) não devem ser usadas em lactentes. Na técnica das compressões torácicas no lactente, o reanimador deve deita-lo em decúbito dorsal, com a cabeça mais baixa, 


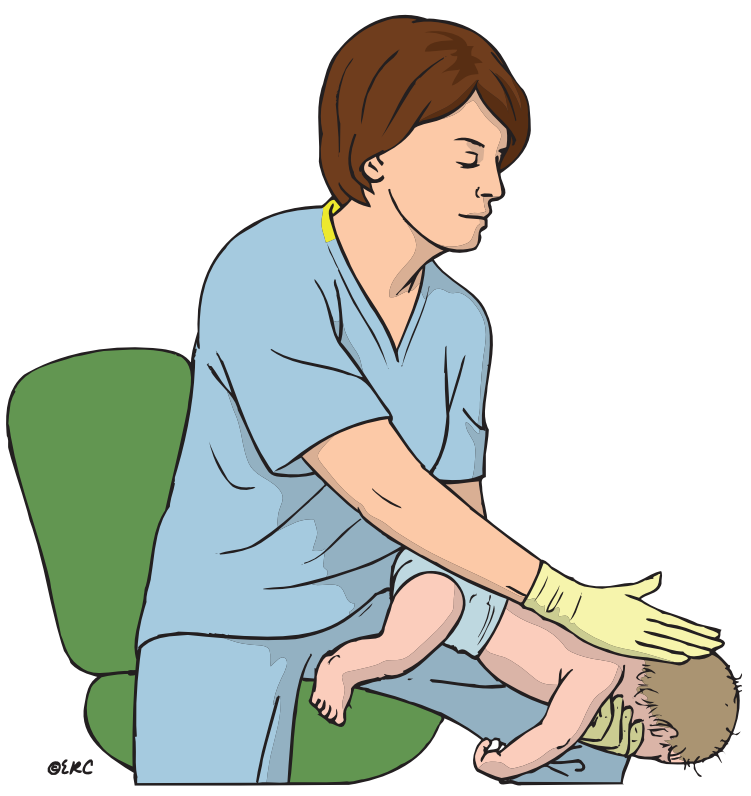

@ European Ressuscitation Council - www.erc.edu - 2017_NGL_008

Figura 19. Pancadas interescapulares no lactente consciente.

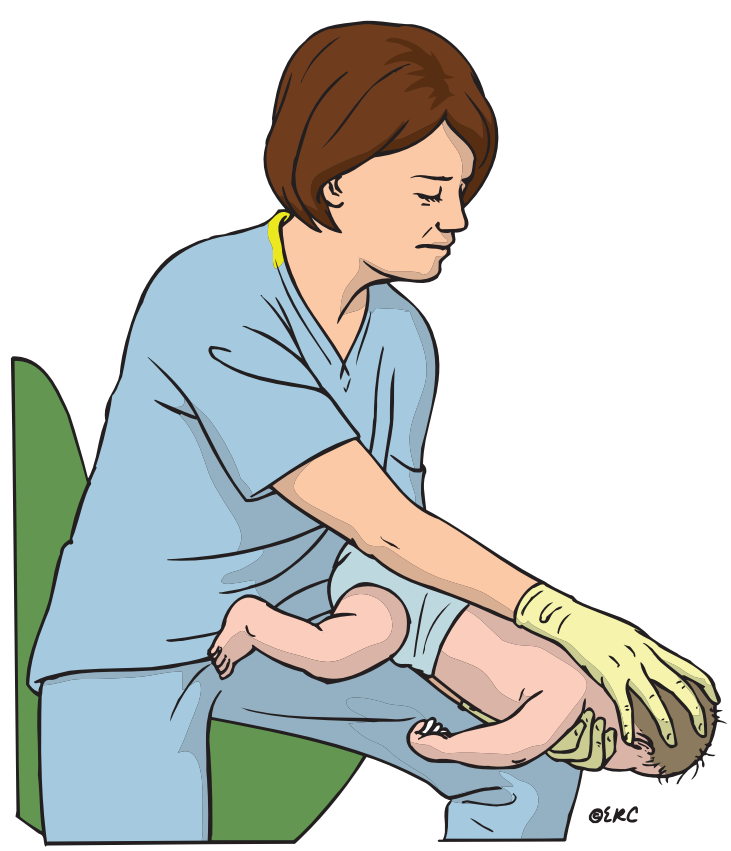

(c) European Ressuscitation Council - www.erc.edu - 2017_NGL_008

Figura 20. Manobra para voltar o lactente.

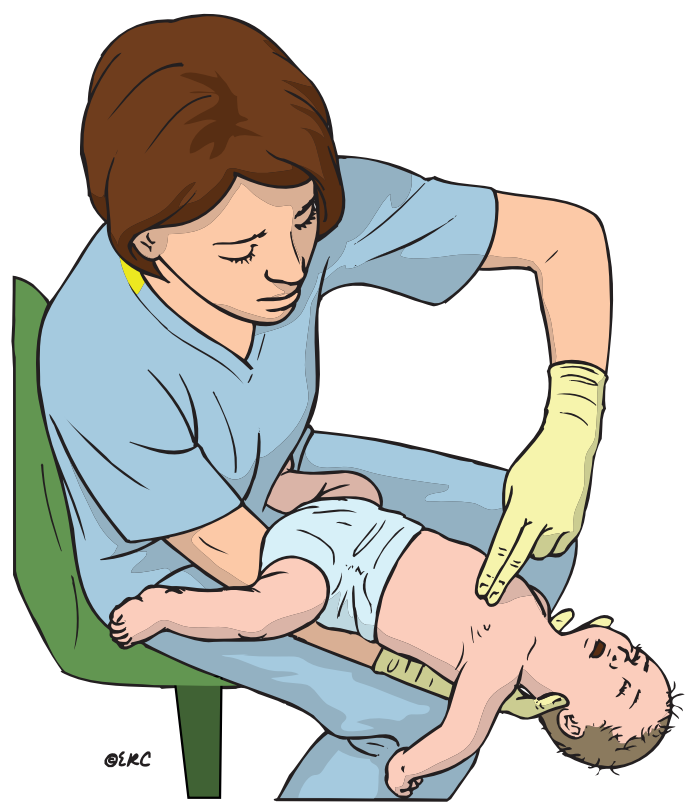

@ European Ressuscitation Council - www.erc.edu - 2017_NGL_008

Figura 21. Compressões torácicas no lactente consciente.

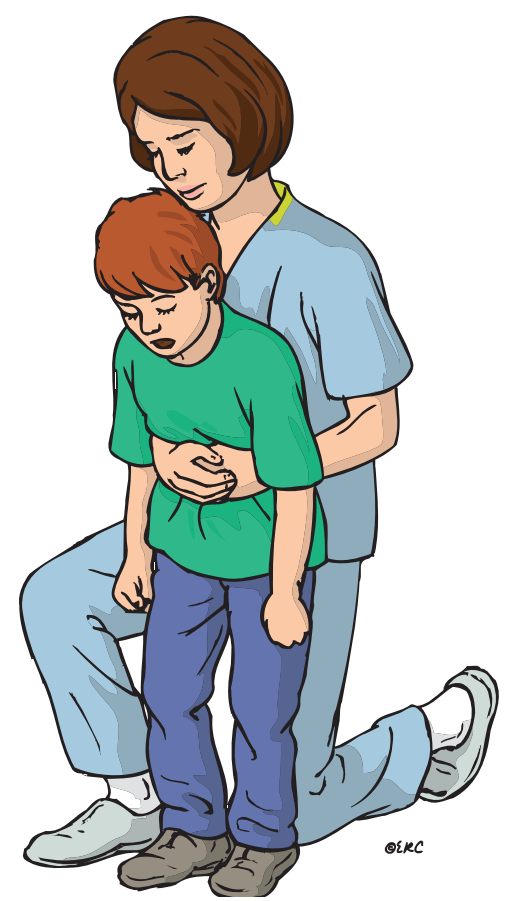

(C) European Ressuscitation Council - www.erc.edu - 2017_NGL_008

Figura 22. Compressão abdominal na criança. 


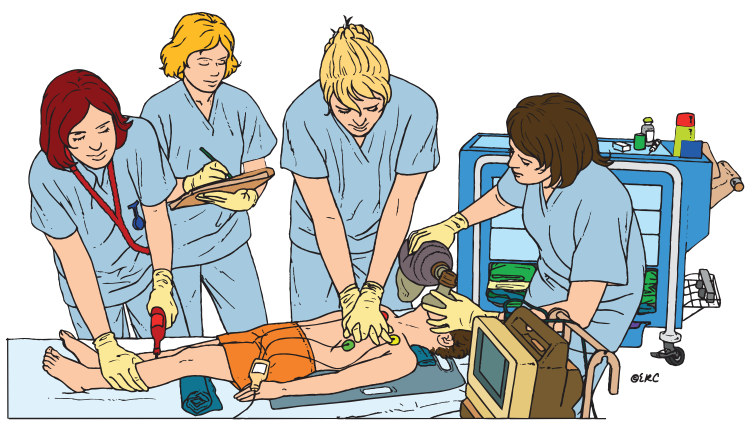

๑) European Ressuscitation Council - www.erc.edu - 2017_NGL_008

Figura 23. Trabalho de equipa.

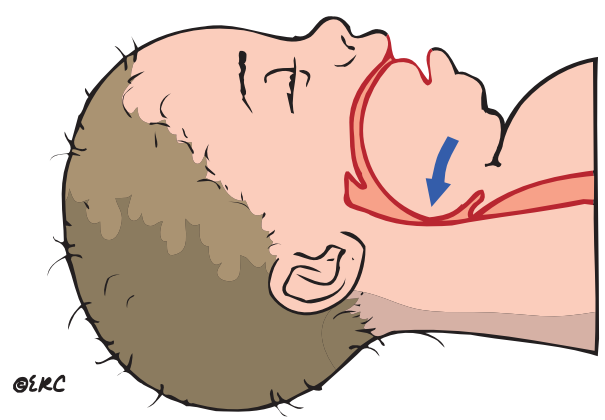

() European Ressuscitation Council - www.erc.edu - 2017_NGL_008

Figura 24. Criança inconsciente; a queda da língua produz obstrução da via aérea.

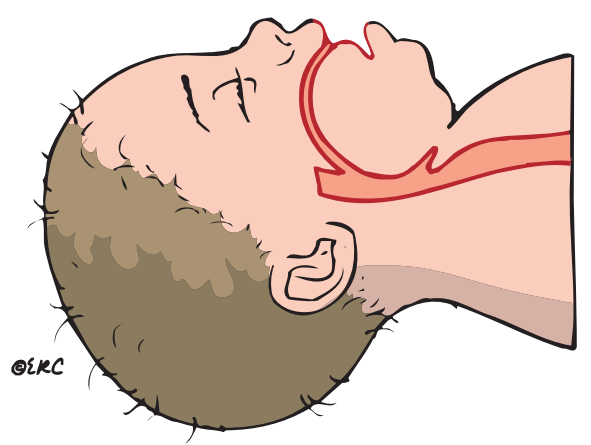

(c) European Ressuscitation Council - www.erc.edu - 2017_NGL_008

Figura 25. Após um ano de idade, a extensão do pescoço melhora a patência da via aérea.

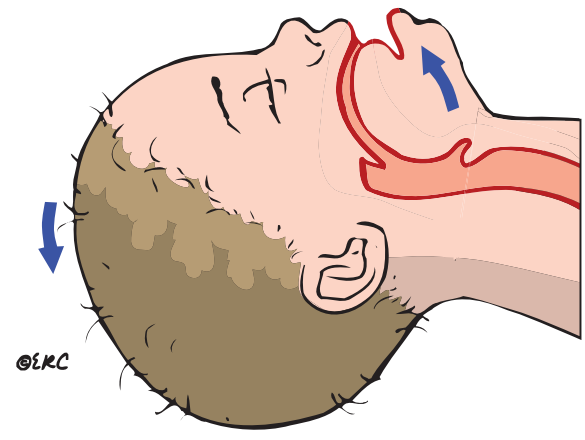

(C) European Ressuscitation Council - www.erc.edu - 2017_NGL_008

Figura 26. Extensão com elevação do queixo aumenta a patência da via aérea, elevando a porção anterior da língua.

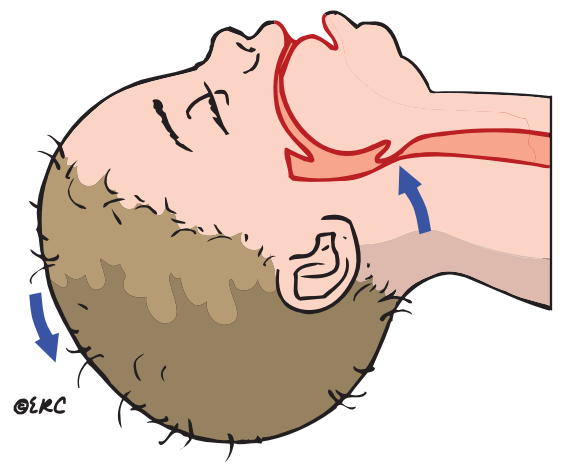

@ European Ressuscitation Council - www.erc.edu - 2017_NGL_008

Figura 27. Hiperextensão causa obstrução da via aérea.

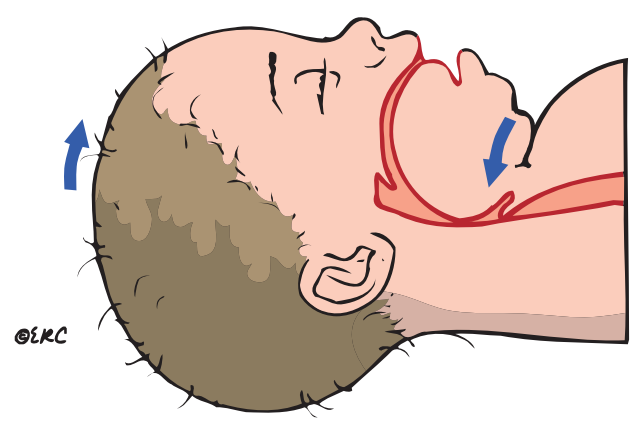

๑ European Ressuscitation Council - www.erc.edu - 2017_NGL_008

Figura 28. Flexão do pescoço também causa obstrução da via aérea. 
colocando o dorso ao longo do seu braço livre e apoiando o occipital sobre a mão, figuras 20 e 21. O lactente fica assim apoiado ao longo do braço do reanimador, por sua vez apoiado na coxa. Localiza-se a referência para a compressão torácica (metade inferior do esterno cerca de um dedo acima do apêndice xifoide). Devem ser efetuadas até cinco compressões. Estas são semelhantes às compressões torácicas do SBV, mas mais secas e a um ritmo mais lento.

Nas compressões abdominais na criança, o reanimador coloca-se de pé ou ajoelhado atrás desta e passa os seus braços por baixo dos braços da criança, envolvendo o tronco pela frente. O reanimador fecha um punho e coloca-o entre o umbigo e o apêndice xifoide. Apertando esse punho com a outra mão, o reanimador puxa de modo seco para trás e para cima aplicando até cinco compressões abdominais, figura 22. É preciso ter cuidado para não aplicar pressão sobre o esterno e a grelha torácica que provoque trauma. Se o corpo estranho não for expelido e a criança se mantiver consciente, continuar a sequência de pancadas interescapulares e compressões (torácicas em lactentes e abdominais nas outras crianças), chamar ajuda, ou mandar chamar. Se o corpo estranho tiver sido expulso, avaliar a situação clinica. Uma parte do objeto pode permanecer no trato respiratório e causar complicações. As compressões abdominais podem causar lesões internas, por isso todas as vítimas devem ser observadas em meio hospitalar. Se uma criança com OVACE está inconsciente, o reanimador deve deita-la numa superfície dura e plana, iniciar SVB e pedir ajuda. Pode-se abrir a boca, procurar o objeto e se facilmente visível, fazer uma tentativa de o remover com uma única passagem de um dedo. Não tentar limpezas com o dedo de um modo cego ou repetido, já que podem causar lesões ou empurrar o objeto.

\subsubsection{Suporte avançado de vida pediátrico}

A abordagem do suporte avançado de vida pediátrico (SAV pediátrico) é estabelecida seguindo o ABCDE. No A e B deve-se permeabilizar a via aérea, otimizar a ventilação, assegurar um correta oxigenação (iniciar com $\mathrm{FiO}_{2}$ de100\%) e monitorizar a $\mathrm{SpO}_{2}$ com oximetria de pulso. Para otimizar a ventilação pode ser necessário utilizar adjuvantes da via aérea e executar a técnica de ventilação com máscara e insuflador. A intubação traqueal não será descrita nesta lição pois em contexto de paragem cardio-respiratória deve ser apenas efetuada por profissionais treinados. A abordagem da circulação (C) na paragem cardio-respiratória inclui as compressões torácicas (técnica igual ao descrito no SBV), monitorização com ECG, $\mathrm{SpO}_{2} \mathrm{e}$ pressão arterial, obtenção de um acesso vascular e desfibrilhação. Na figura 23 pode ser observado o trabalho de equipa nesta situação.

A permeabilidade da via área deve ser assegurada de acordo com a abordagem do SBV. Nas figuras 24 a 28 pode ser observada a importância do posicionamento da cabeça a que já se chamou a atenção previamente.

A faringe pode ser obstruída por secreções, vómito ou sangue. Pode ser necessário usar um equipamento de aspiração para permeabilizar a via aérea. Este inclui um aspirador fixo, geralmente com regulador da pressão negativa, um 
reservatório, tubos de aspiração e sondas de aspiração adequadas. As sondas de aspiração rígidas e de grande calibre (i.e. sondas de Yankauer) são especialmente úteis para a remoção de vómito ou secreções espessas e abundantes. As sondas flexíveis são mais adequadas para lactentes ou crianças pequenas, porque são menos traumáticas; no entanto a sua capacidade de aspiração é mais limitada. Para se poder controlar a pressão de aspiração pode usar-se uma peça em Y ou um orifício lateral que se oclui intermitentemente. Nas crianças com reflexo de engasgamento presente a aspiração deve ser efetuada com precaução pelo risco de induzir o vómito. Uma aspiração mais prolongada ou enérgica pode causar estimulação vagal com bradicardia.

As vias orofaríngeas (cânulas de Guedel) ou adjuvantes da via aérea, podem ser úteis na criança inconsciente sem reflexo de engasgamento, figuras 29 a 31. Deve ser utilizado um tamanho correto, figura 30, avaliado pela distância entre os incisivos e o ângulo da mandibula, para evitar o agravamento da obstrução, trauma ou desencadear laringoespasmo. Na criança, a via orofaríngea deve ser introduzida com cuidado e sem forçar para não lesar o palato mole. Pode ser inserida diretamente com a concavidade para baixo, usando uma espátula ou uma lâmina de laringoscópio para baixar a língua. Após inserção de uma via orofaríngea, deve verificar-se a patência da via aérea e administrar oxigénio, ou ventilar, consoante necessário.

A administração de oxigénio deve ser tão precoce quanto possível. Inicialmente, deve ser fornecida a maior concentração disponível. Uma máscara de oxigénio com reservatório é a

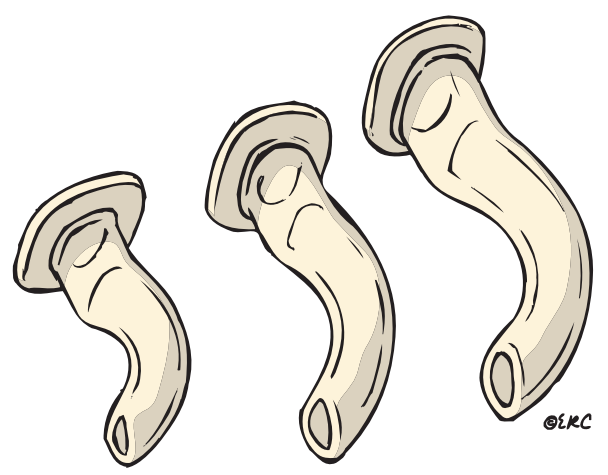

C European Ressuscitation Council - www.erc.edu - 2017_NGL_008

Figura 29. Vias orofaríngeas.

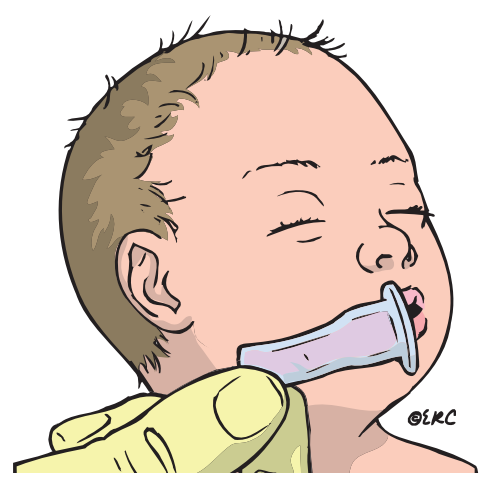

C European Ressuscitation Council - www.erc.edu - 2017_NGL_008

Figura 30. Estimativa da dimensão apropriada de via orofaríngea (dos incisivos ao ângulo da mandibula).

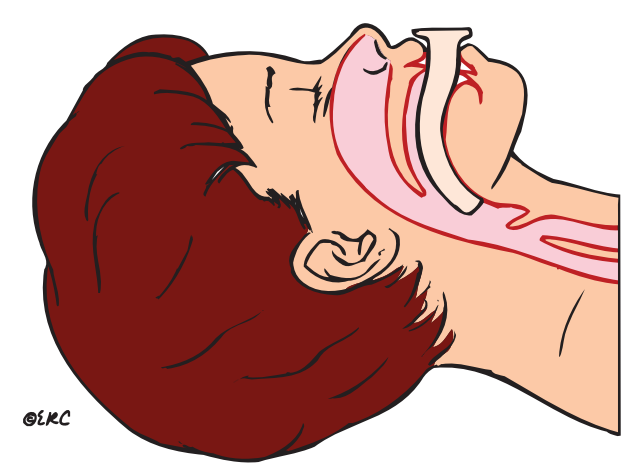

C European Ressuscitation Council - www.erc.edu - 2017_NGL_008

Figura 31. Via orofaríngea colocada. 


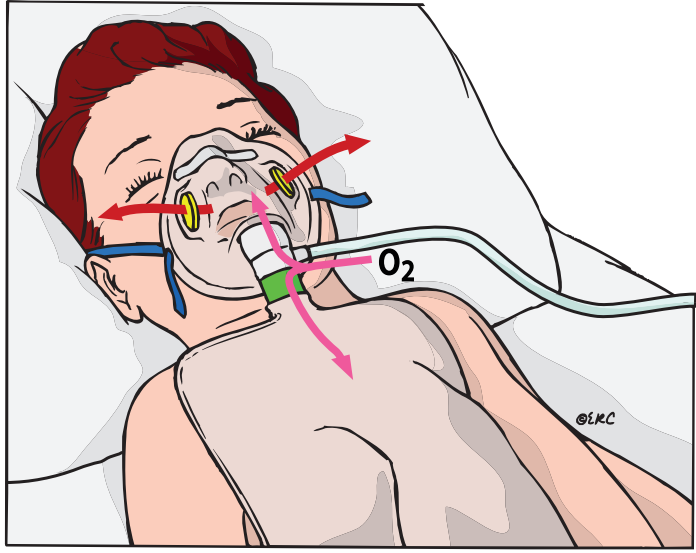

(C) European Ressuscitation Council - www.erc.edu - 2017_NGL_008

Figura 32. Máscara facial: com válvulas unidirecionais, durante a inspiração o oxigénio é fornecido apenas a partir do reservatório e da fonte de oxigénio. Durante a expiração, válvulas unidirecionais permitem exalação e evitam reinalação.

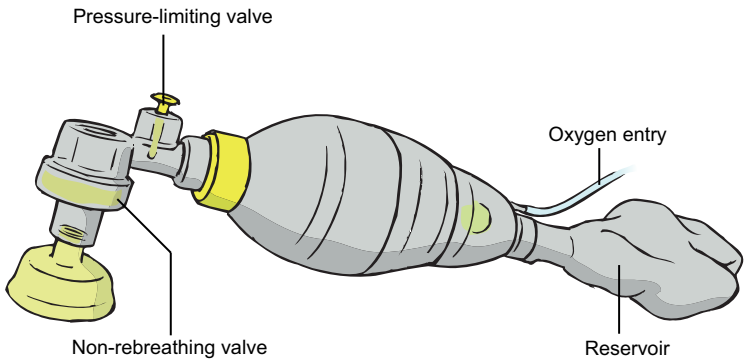

๑) European Ressuscitation Council - www.erc.edu - 2017_NGL_008

Figura 33. Insuflador auto-insuflável com acumulador, o que permite $\mathrm{FiO}_{2}$ mais elevada.

primeira escolha na criança gravemente doente em respiração espontânea. O débito de oxigénio deve ser suficiente para evitar o colapso do reservatório durante a inspiração. Estas máscaras estão equipadas com válvulas unidirecionais entre o reservatório e a máscara e com válvulas que cobrem os orifícios expiratórios, para evitar a reinalação, figura 32. Desde que haja uma boa adaptação da máscara à face, permitem obter concentrações de oxigénio no ar inspirado de $90 \%$ ou mais, com um débito de 12 a 15 litros de oxigénio por minuto.

Quando uma criança respira de forma inadequada ou não respira, após manter a permeabilidade da via aérea é necessário iniciar ventilação. Numa fase inicial, o melhor método é usar um insuflador manual autoinsuflável, de tamanho adequado, conectado a uma máscara, figura 33. A entubação traqueal apenas deve ser tentada por quem tenha competência e experiência nessa manobra. O reanimador deve efetuar ventilação com pressão positiva com uma frequência de 12 a $20 \mathrm{cpm}$ em lactentes e crianças. O volume corrente conseguido deve evidenciar uma expansão torácica adequada e sons audíveis na auscultação pulmonar. Deve evitar-se a hiperventilação.

Saber executar corretamente ventilação com máscara e insuflador é uma competência fundamental para todos os profissionais de saúde que trabalham com crianças. Mesmo que seja necessária entubação traqueal, a ventilação com máscara e insuflador (VMI) está sempre rapidamente disponível e pode garantir uma ventilação eficaz na maioria das crianças, até chegar ajuda especializada. A máscara deve ter tamanho adequado, ser transparente e permitir uma boa selagem em volta do nariz e boca, garantindo que não se aplica pressão sobre os olhos. São necessárias duas mãos para efetuar a VMI. Uma das mãos segura a máscara, ao mesmo tempo que efetua uma manobra modificada de subluxação da mandibula; a outra mão comprime o balão, figuras 34 e 35. Para avaliar a eficácia da ventilação deve observar-se cuidadosamente a expansão torácica. 

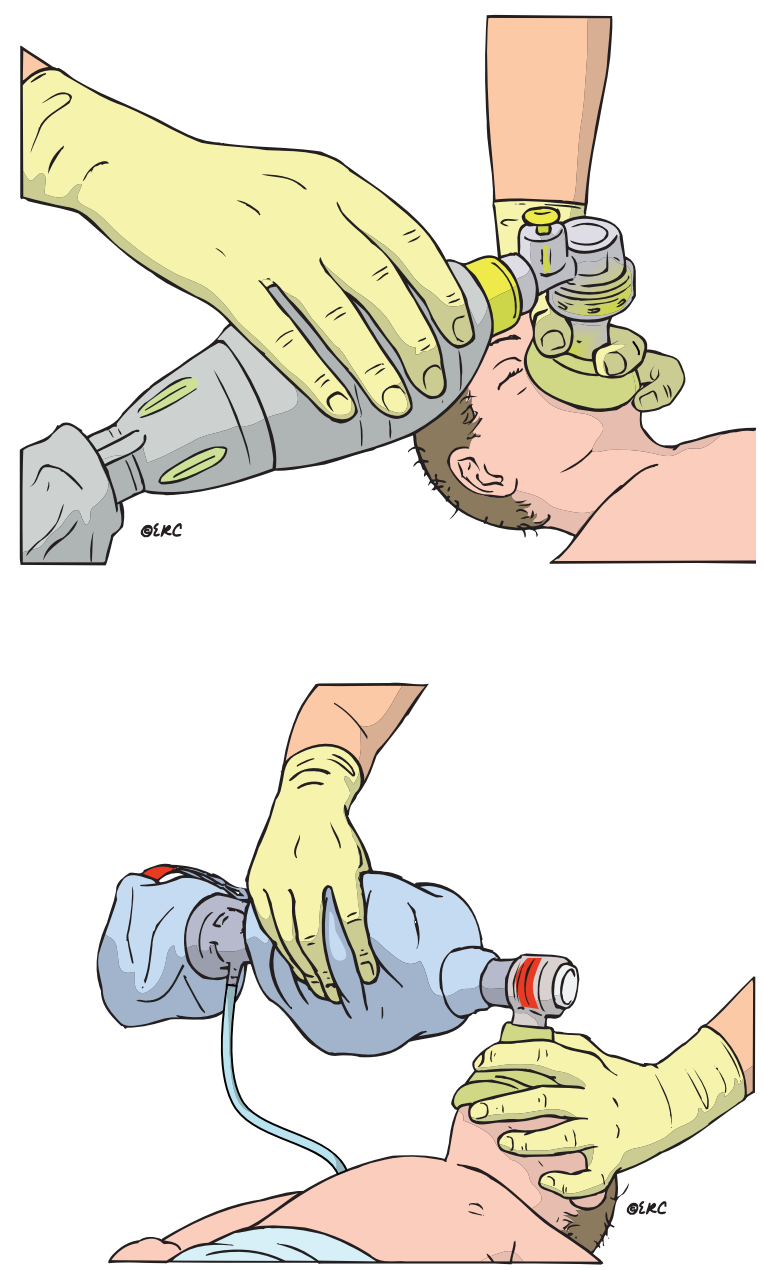

๑) European Ressuscitation Council - www.erc.edu - 2017_NGL_008

Figuras 34 e 35. A máscara é segura com uma mão com a técnica "E-C clamp", com abertura simultânea da via aérea. Forma-se um " $E$ " com o terceiro, quarto e quinto dedos na mandibula e um "C" com o polegar e indicador na máscara.

Após a abordagem da via aérea $(A)$ e respiração (B), segue-se a circulação (C). A obtenção de um acesso venoso é essencial nos primeiros minutos da reanimação, mas não deve interromper as compressões e a ventilação. Este acesso pode ser conseguido por via intravenosa periférica ou por via intra-óssea (IO). Esta última é a via de escolha nos casos de paragem cardio-respiratória

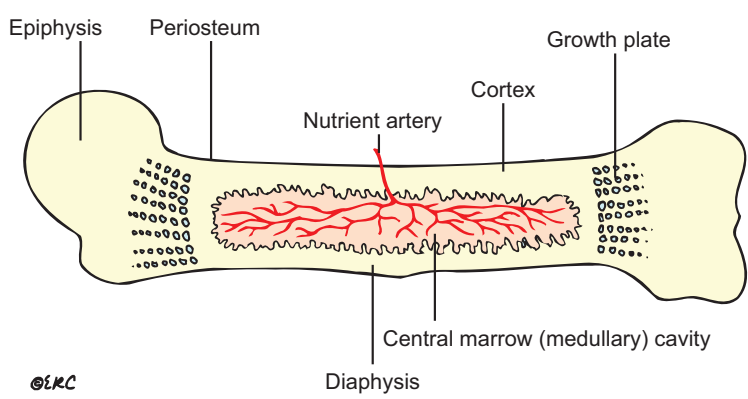

(C) European Ressuscitation Council - www.erc.edu - 2017_NGL_008

Figura 36. Anatomia de um osso longo.

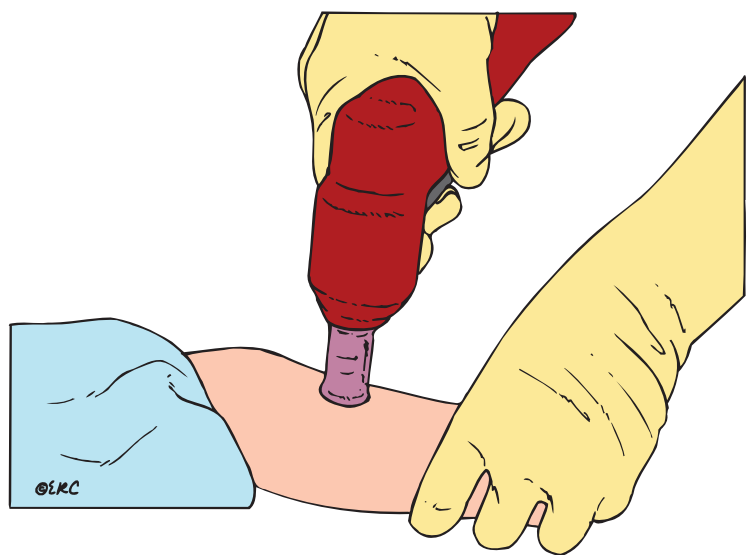

๑ European Ressuscitation Council - www.erc.edu - 2017_NGL_008

Figura 37. Dispositivo tipo berbequim para inserção de agulha intra-óssea.

e choque descompensado. As localizações anatómicas para introdução de agulhas 10 são:

1.abaixo dos seis anos: superfície antero-interna da tíbia, 2 a $3 \mathrm{~cm}$ abaixo e para dentro da tuberosidade;

2. seis anos ou mais: na face interna da tíbia $3 \mathrm{~cm}$ acima do maléolo interno ou na 
face lateral externa do fémur, $3 \mathrm{~cm}$ acima do côndilo lateral ou na face anterior da cabeça do úmero (adolescentes).

Estes locais permitem evitar as placas de crescimento dos ossos longos (metáfises), figura 36. A agulha atravessa o periósteo e o córtex até à cavidade medular. A inserção da agulha 10 e a primeira administração de fluidos podem ser dolorosas. Em crianças conscientes, a pele e o periósteo devem ser infiltrados com lidocaína a 1\%.

A técnica de inserção de agulha intra-óssea consiste em:

1. Identificar o local de entrada.

2. Limpar a pele circundante com uma solução de base alcoólica.

3. Infiltrar a pele, até ao periósteo, com lidocaína a 1\% (em crianças conscientes).
4. Imobilizar o membro com a mão não dominante (garantir que a mão não fica por baixo do membro).

5. Com a mão dominante, o reanimador segura firmemente a agulha num ângulo de $90^{\circ}$ em relação à pele já preparada.

6. Avançar a agulha com movimentos firmes de rotação a $90^{\circ}$, até ter uma sensação de cedência, no momento em que o córtex é atravessado. A agulha deve entrar aproximadamente um a dois $\mathrm{cm}$. Se for usado um dispositivo automático tipo berbequim, colocar a agulha firmemente na pele e começar a ativar o motor sem forçar, figura 37. Parar quando se sente ceder. O comprimento introduzido depende do tipo de dispositivo usado.

7. Após remover o mandril, conectar um curto prolongador com uma torneira de três

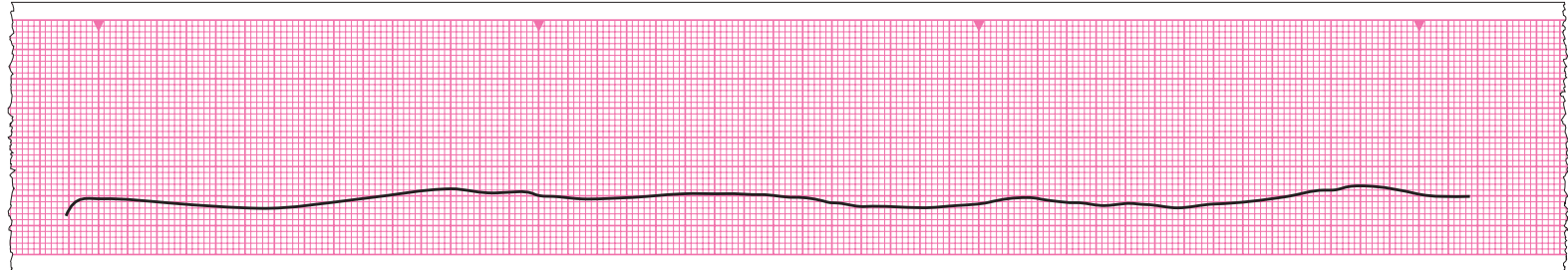

C European Ressuscitation Council - www.erc.edu - 2017_NGL_008

Figura 38. Assistolia.

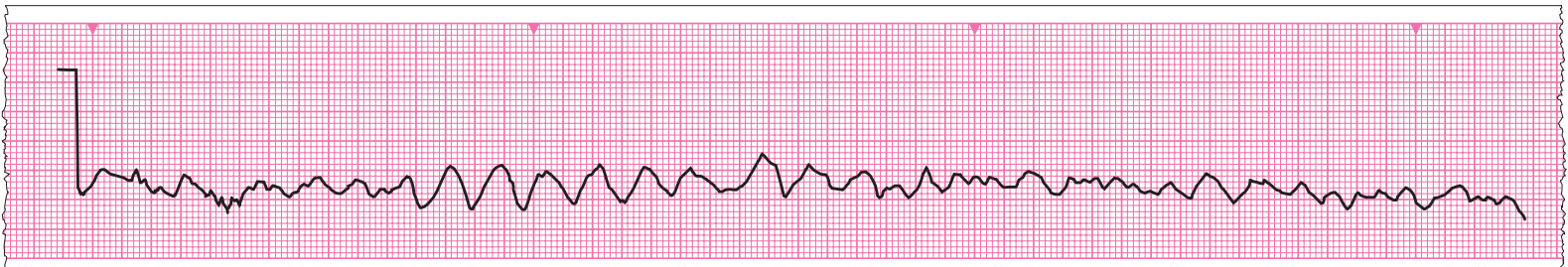

C European Ressuscitation Council - www.erc.edu - 2017_NGL_008

Figura 39. Fibrilhação ventricular fina. 
vias ligada a uma seringa e ao reservatório de fluidos. Aspirar sangue ou injetar soro para confirmar o posicionamento correto. Não se deve notar infiltração dos tecidos subcutâneos. Se a colheita não atrasar a administração de fluídos e fármacos, deve ser obtida uma amostra de sangue para hemograma, classificação e outras análises consideradas pertinentes.

8. Administrar os fármacos de reanimação seguidos de bólus de dois a dez $\mathrm{mL}$ de soro fisiológico e/ou bólus de outros fluídos se indicados. Os bólus de fluídos de grande volume devem ser injetados com uma pressão cuidadosa.

9. Após ter penetrado na cavidade medular a agulha ficará estável e não necessita de fixação com adesivos. No entanto, deve ser assegurado que não se remova acidentalmente, principalmente durante o transporte.

O reconhecimento do ritmo através da monitorização com ECG é prioritário pois é necessário definir se o ritmo é ou não desfibrilhável. A abordagem da paragem cardio-respiratória (ritmos desfibrilháveis e não desfibrilháveis) está detalhada nos algoritmos de suporte avançado de vida pediátrico, figuras 42 a 44 . Nos ritmos não desfibrilháveis (assistolia e AESP) é necessário fazer compressões torácicas e nos desfibrilháveis (FV e TV sem pulso), compressões e desfibrilhação. A assistolia caracteriza-se pela ausência total de atividade elétrica e mecânica do coração, figura 38 .

Na AESP ocorre atividade elétrica organizada na ausência de sinais de vida ou pulso central. O ECG observado pode apresentar diversas variantes de complexos QRS normais mas rapidamente evoluem para complexos largos e anómalos. Todos os ritmos de paragem cardíaca, mas particularmente a AESP, podem ser devidos a uma causa reversível subjacente. A FV consiste numa série caótica e desorganizada de despolarizações com ondas e complexos anormais. Como não ocorre sístole ventricular, não há pulso palpável. A FV pode ser descrita como fina ou grosseira dependendo da amplitude dos complexos, figuras 39 e 40. A TV sem pulso é rara em crianças. Caracteriza-se por uma frequência ventricular de 120 a 400 bpm, com complexos largos e regulares, mas sem pulso figura 41.

A obtenção de informação relevante acerca da situação clinica prévia da criança e de fatores predisponentes pode ser útil para determinar causas e otimizar a abordagem da paragem cardio-respiratória. Todas as causas com um tratamento específico possível devem ser sistematicamente consideradas e corrigidas. Para recordar as mais frequentes, usa-se a mnemónica 4Hs (hipóxia, hipovolémia, hipo ou hipercaliémia e hipotermia) e 4Ts (pneumotórax de tensão, tóxicos, tamponamento cardíaco e tromboembolia). 


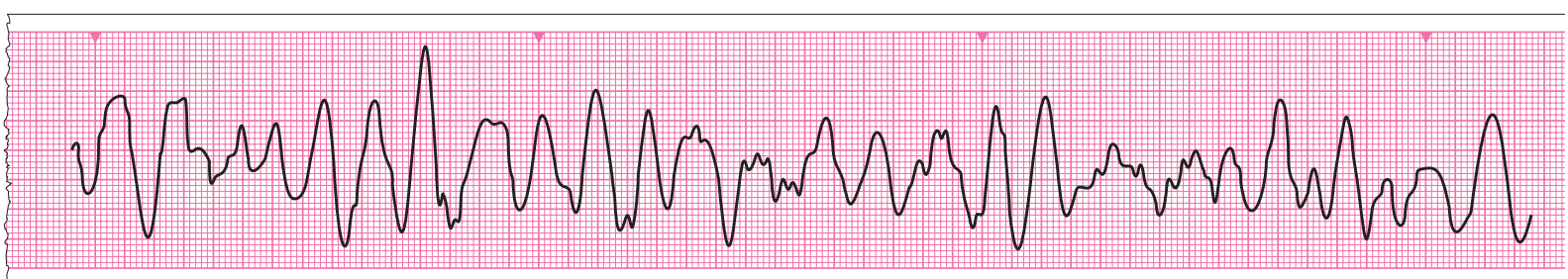

C European Ressuscitation Council - www.erc.edu - 2017_NGL_008

Figura 40. Fibrilhação ventricular grosseira.

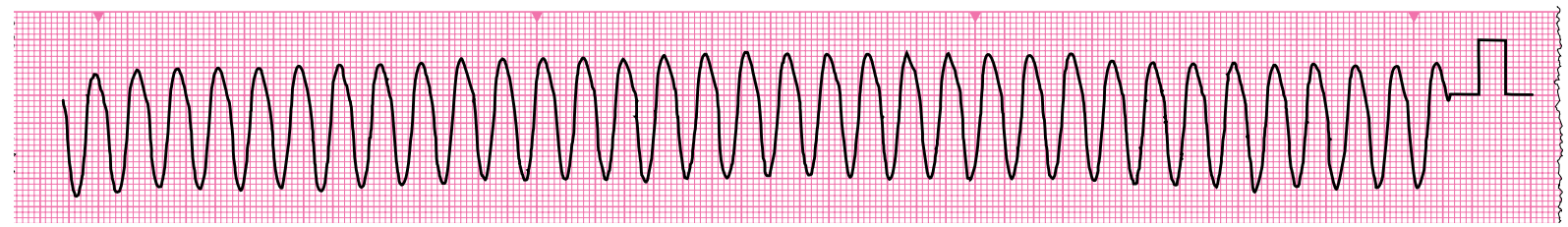

C European Ressuscitation Council - www.erc.edu - 2017_NGL_008

Figura 41. Taquicardia ventricular. 


\section{Suporte Avançado de Vida Pediátrico}

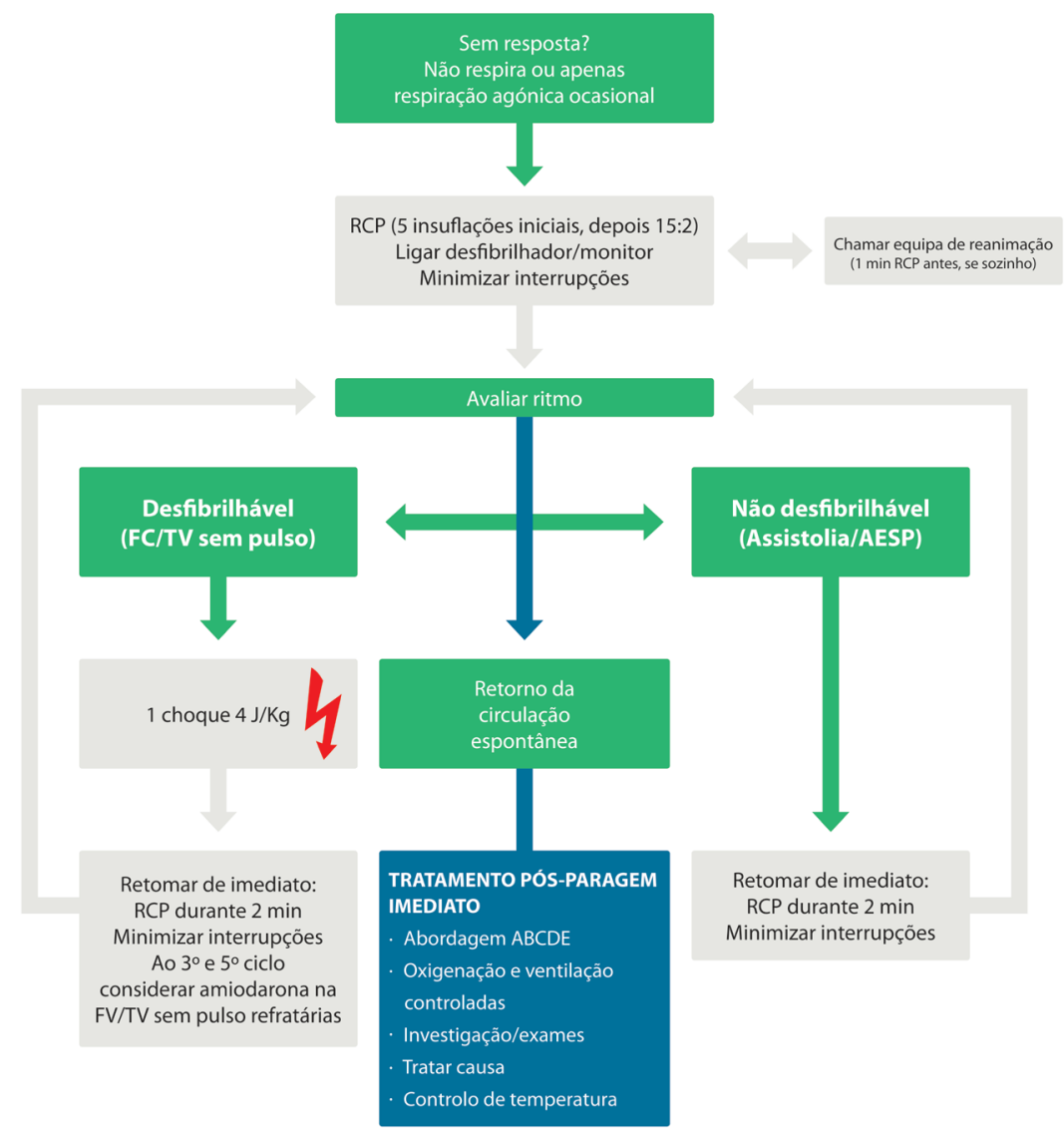

DURANTE RCP
- Manter RCP de qualidade: frequência, profundidade,
descompressäo
- Planear atitudes antes de interromper RCP
- Administrar oxigénio
- Acesso vascular (intravenoso, intra-ósseo)
- Adrenalina a cada 3-5 min
- Considerar via aérea avançada e capnografia
- Compressōes torácicas contínuas quando via aérea avançada
colocada
- Corrigir causas reversiveis

CAUSAS REVERSIVEIS
- Hipóxia
- Hipovolémia
- Hiper/hipocalémia, metabolica
- Hipotermia
- Trombose (coronária ou pulmonar)
- Pneumotórax de tensão
- Tamponamento (cardiaco)
- Alteraçōes tóxicas/fármacos

Figura 42. Algoritmo do SAV pediátrico. RCP - reanimação cardio-pulmonar; FV - fibrilhação ventricular; TV - taquicardia ventricular; AESP - atividade elétrica sem pulso 


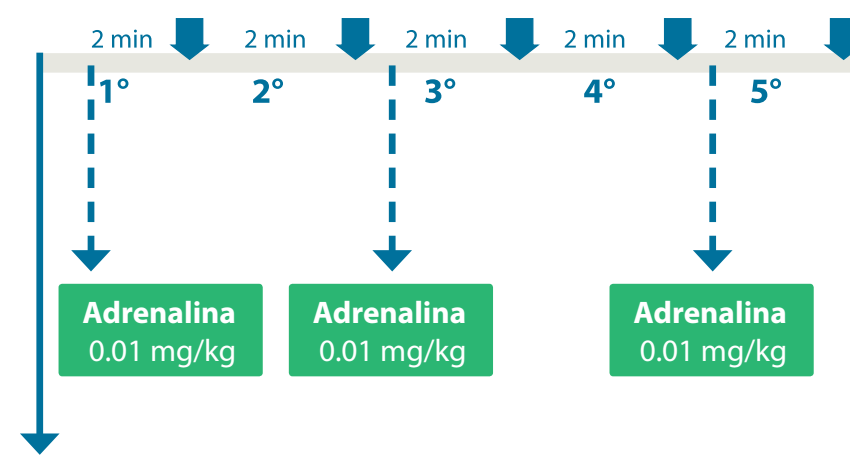

Ventilar / Oxigenar

Acesso Vascular IO / IV

Fármacos Intubação

(c) European Ressuscitation Council - www.erc.edu - 2017_NGL_008

Figura 43 - Algoritmo pediátrico para ritmos não desfibrilháveis. IO - intra-ósseo; IV - intravenoso

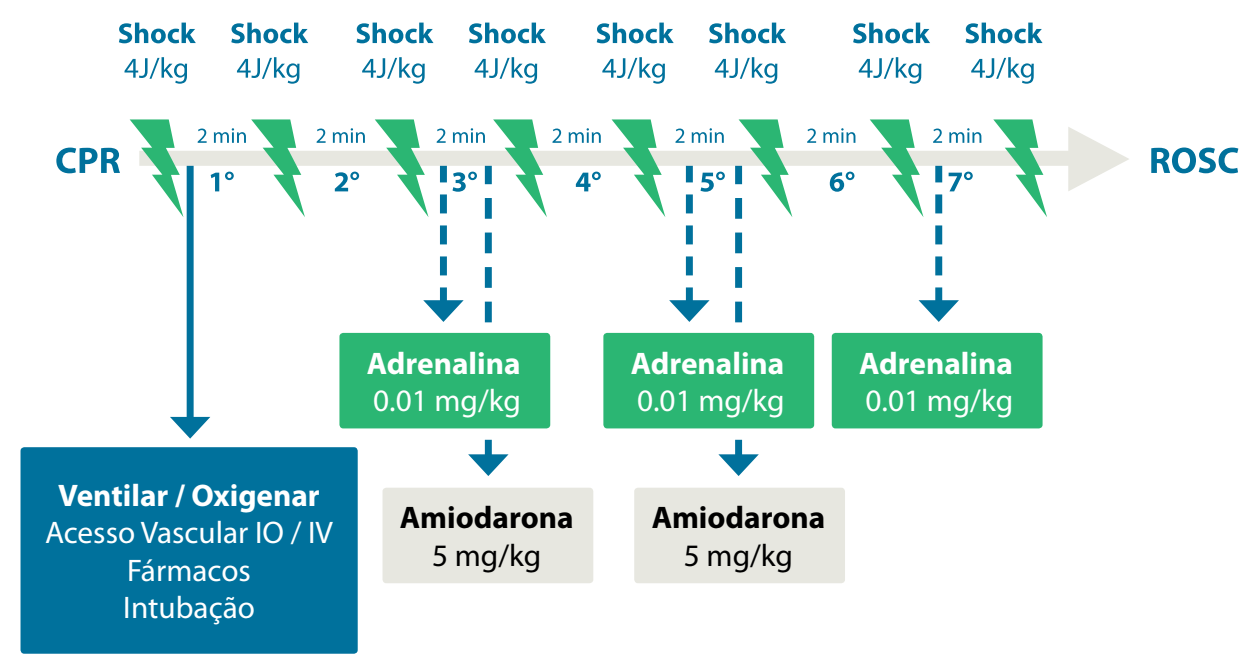

C European Ressuscitation Council - www.erc.edu - 2017_NGL_008

Figura 44. Algoritmo pediátrico para ritmos desfibrilháveis. IO - intra-ósseo; IV - intravenoso; CPR - cardiopulmonary ressuscitation; ROSC - return of spontaneous circulation. 